\title{
Teleost microbiomes: the state of the art in their characterization, manipulation and importance in aquaculture and fisheries
}

\author{
Martin S. Llewellyn ${ }^{1,2+}$, Sébastien Boutin ${ }^{1+}$, Seyed Hossein Hoseinifar ${ }^{3 \dagger}$ and Nicolas Derome ${ }^{1 * t}$ \\ 1 Département de Biologie, Institut de Biologie Intégrative et des Systèmes, Université Laval, Québec, OC, Canada \\ ${ }^{2}$ Molecular Ecology and Fisheries Genetics Laboratory, School of Biological Sciences, University of Wales, Bangor, UK \\ ${ }^{3}$ Department of Fisheries, Gorgan University of Agricultural Sciences and Natural Resources, Gorgan, Iran
}

\author{
Edited by: \\ David Georges Biron, Centre \\ National de la Recherche \\ Scientifique, France \\ Reviewed by: \\ Ryan J. Newton, University of \\ Wisconsin-Milwaukee, USA \\ Jaime Romero, Universidad de \\ Chile, Chile \\ *Correspondence: \\ Nicolas Derome, Département de \\ Biologie, Institut de Biologie \\ Intégrative et des Systèmes, \\ Université Laval, Pavillon \\ Alexandre-Vachon, 1045, av. de la \\ Medecine, Local 3058, Québec, \\ OC GIV OA6, Canada \\ e-mail:nicolas.derome@bio.ulaval.ca \\ t'These authors have contributed \\ equally to this work.
}

Indigenous microbiota play a critical role in the lives of their vertebrate hosts. In human and mouse models it is increasingly clear that innate and adaptive immunity develop in close concert with the commensal microbiome. Furthermore, several aspects of digestion and nutrient metabolism are governed by intestinal microbiota. Research on teleosts has responded relatively slowly to the introduction of massively parallel sequencing procedures in microbiomics. Nonetheless, progress has been made in biotic and gnotobiotic zebrafish models, defining a core microbiome and describing its role in development. However, microbiome research in other teleost species, especially those important from an aquaculture perspective, has been relatively slow. In this review, we examine progress in teleost microbiome research to date. We discuss teleost microbiomes in health and disease, microbiome ontogeny, prospects for successful microbiome manipulation (especially in an aquaculture setting) and attempt to identify important future research themes. We predict an explosion in research in this sector in line with the increasing global demand for fish protein, and the need to find sustainable approaches to improve aquaculture yield. The reduced cost and increasing ease of next generation sequencing technologies provides the technological backing, and the next 10 years will be an exciting time for teleost microbiome research.

Keywords: fish, microbiota, probiotics, aquaculture, fisheries

\section{INTRODUCTION}

The bacteria that colonize the internal and external epidermal surfaces of metazoans are thought to outnumber their host cells by at least 10 to 1 (Human Microbiome Project, 2012). Adult humans contain over a kilogram of such organisms (Ley et al., 2008; Human Microbiome Project, 2012; Karlsson et al., 2013). The emergence and evolution of metazoan organisms has undoubtedly involved close partnership with bacterial life. As such, the relationship that exists between vertebrates and their bacterial colonists dates back hundreds of millions of years (Ley et al., 2008). The microbial metagenome dwarfs that of their hosts (Qin et al., 2010). Numerous metabolic processes vital for host fitness and survival may be assigned to, or facilitated by, their microbial community.

Definition of the services provided by a host microbiome depends on our ability to establish its composition and functional capacity. Furthermore, functional stability in space and time may provide clues to recruitment and host fitness constraints on community structure (Costello et al., 2009; Turnbaugh et al., 2009a). Next-generation sequencing techniques, including amplicon and shot-gun approaches, and associated bioinformatic tools have revolutionized our ability to count and classify commensal bacteria. Concurrently, DNA database development for reliable classification of taxonomy (e.g., GreenGenes,
Silva), and functionality (e.g., UniProt, Swiss-prot) has facilitated data interpretation. Large-scale multi-partner projects, particularly the Human Microbiome Project (2012), have driven much of the tool development in this area and are also responsible for the instigation of standard operating procedures to facilitate comparisons between samples, centers, and studies. As such, sophisticated hypotheses across large and dispersed cohorts of individuals can be addressed including the impacts of lifestyle, (e.g., Turnbaugh et al., 2006), disease (Morgan et al., 2012), and antibiotic treatment (Perez-Cobas et al., 2013). Studies frequently document perturbations in meta-community structure that accompany these phenomena as well as perturbations that may have a predictive value for certain metabolic diseases (collectively called dysbiosis) (Karlsson et al., 2013). More important still is to establish a causal link between dysbiosis (imbalance in the microbiome) and pathology. In proving causality, "forward microbiomics" are highly attractive (introducing artificial or transplanting microbiomes into naïve hosts). Humanized germ free (gnotobiotic) mouse models, transplanted with human fecal microbiomes, have corroborated dietary microbiome shifts observed in the clinic (Turnbaugh et al., 2009b). Furthermore, transplantation of "obese" human microbiomes into germ-free animals can modulate mouse metabolism toward adiposity and increased body mass (Ridaura et al., 2013). 
Teleost microbiome research lags well behind that in humans and mouse models. Nonetheless, thanks in part to the efforts of Rawls and collaborators, the nature of the Zebra fish gut microbiome was established relatively early in the meta-sequencing goldrush. Their work revealed fascinating reciprocal differences between mammalian and teleost microbiota, as well as the first gnotobiotic teleost model (Rawls et al., 2006). Later studies revealed a "core microbiome" among this species, dominated by $\gamma$-Proteobacteria and enriched with a diverse assemblage of Fusobacteria species (Roeselers et al., 2011). Importantly, striking similarities were observed between the microbiomes of domesticated and wild individuals, implying a role for host selection on microbiota, and to an extent validating the conclusions of previous laboratory studies. As well as D. reria, several other teleost species have had their microbiota scrutinized via either culture dependent or independent techniques. Studies conducted to date, the tools used and species examined, are summarized in Table 1, and a broad overview of their rather incomplete findings in Figure 1. Unsurprisingly the focus has been aquaculture species, although some wild individuals have also been studied. Overall there has been important progress in recent years, albeit uncoordinated and sporadic.

In humans, our burgeoning understanding of our "second genome" is driving research into disease, nutrition, lifestyle, as well as immunity and development, (e.g., Furusawa et al., 2013). The applications of an improved understanding in terms of biomarkers, modulation of dysbiotic microbiomes with pre- and pro- biotics, treatment of infectious disease, as well as the generation of totally artificial microbiomes, are considerable. In teleosts, and especially in aquaculture, these applications are equally, if not more, important. Multiple phenomena could be potentially addressed through microbiome manipulation: nutrient digestion, synthesis, absorption, pathogen resistance, growth, sexual maturation, morphogenesis, survivorship in stocked fish, to name a few. In this review we asses the status-quo of teleost microbiome research with special reference to research applications in aquaculture.

\section{TELEOST MICROBIOMES IN HEALTH AND DISEASE TELEOST MICROBIOMES AS BIOMARKERS FOR STRESS}

Aquaculture is a growing industry. Average annual per-capita consumption of fish increased from $12.6 \mathrm{~kg}$ in the $1980 \mathrm{~s}$ to $17.0 \mathrm{~kg}$ in 2007 , meanwhile wild fish stocks are in steep decline (FAO, 2010). Unfortunately, the growing demand for fish has resulted in an intensification that impacts the welfare of animals in aquaculture systems (Ashley, 2007). Fish welfare in aquaculture may be measured via several physiological and behavioral proxies. These proxies can be usefully combined under the phenomenon of stress. The notion of stress in aquaculture is described by Barton and Iwama (1991) as a normal adaptive physiological response to overcome a negative environmental stimulus or disturbance (Barton and Iwama, 1991). In practice stressful stimuli have multiple sources-handling, sorting, grading, transport and stocking, for example. When such stimuli promote a prolonged stress response, the response may be considered maladaptive as the stress becomes detrimental to fish health.
Microbiome balance is known to be key to maintaining overall health in fish (Gómez and Balcázar, 2008). Stress can influence the microbiome in different ways with repercussions for physiological, hormonal and cellular function. The response of the teleost epidermal mucosa to stress is associated with mucus protein compositional shift (Wendelaar Bonga, 1997; Easy and Ross, 2009; Rakers et al., 2010). The composition of the mucosa in turn shapes their microbial community, and there is evidence that stress impacts microbiome diversity in Salvelinus fontinalis (Boutin et al., 2013b). Network analysis of bacterial taxa present in the epidermal mucous of this salmonid during a period of prolonged artificial hypoxic stress revealed interactions between multiple bacterial players in the microbiome. Two taxonomic consortia (co-occuring taxa) emerged (Boutin et al., 2013b). The first consortium, found on unstressed control fish, comprised species from genera Sphingomonas, Methylobacterium, Propionibacterium, and Thiobacter, some of which are associated with pro-biotic and/or anti-microbial activity. The second consortium, found on stressed individuals, contained an array of different putative pathogens from the genera Psychrobacter, Steroidobacter, Pseudomonas, Acinetobacter, and Aeromonas. A conceptual overview of microbiome disruption (or "dysbiosis" as it is often termed) in the epidermal mucous of a teleost is presented in Figure 2.

At the most basic level, microbiome homeostasis (stability) is thought to be under the control of constitutively molecules and receptors of the innate immune system (Dixon et al., 2004). Stress is known to impact immunity in several teleost species (Barton and Iwama, 1991; Iger et al., 1995; Espelid et al., 1996). Teleosts share many components of innate immunity with mammals (Magnadottir, 2006). It seems likely that microbiome shifts in response to stress to an extent reflect a shift in host pattern recognition pathways. Thus, indigenous microbiota represent a valuable extension to the standard behavioral and physiological markers of stress. As we will see, stress related imbalance in the microbiome could be a precursor to disease, and thus of crucial practical importance in aquaculture.

\section{TELEOST MICROBIOMES IN COMMUNICABLE DISEASE}

The immune system and commensal microbiome are though to form an integrative system of defense from communicable disease (Kitano and Oda, 2006). This system operates on two levels. Firstly, there is now good evidence that the presence of commensal bacteria facilitates the development of the vertebrate adaptive immune system (Rakoff-Nahoum et al., 2004; Kelly et al., 2005; Mazmanian and Kasper, 2006; O’Mahony et al., 2008; Hooper et al., 2012). Furthermore, the commensal microbiome inhibits colonization by pathogenic bacteria either passively, via competitive exclusion, or actively, via toxic secondary metabolites. This effect is termed "colonization resistance" (Wells et al., 1988; Balcazar et al., 2006; Stecher and Hardt, 2008). Any disturbance to the commensal microbiome, which results in dysbiosis, can thus enhance susceptibility to disease (Figure 2).

Bacterial pathogens that infect teleosts are found across multiple genera including members of Vibrio, Streptococcus, Aeromonas, Flavobacterium, Photobacterium, Pasteurella, Tenacibacterium, Pseudomonas, Lactococcus, Edwarsiella, 


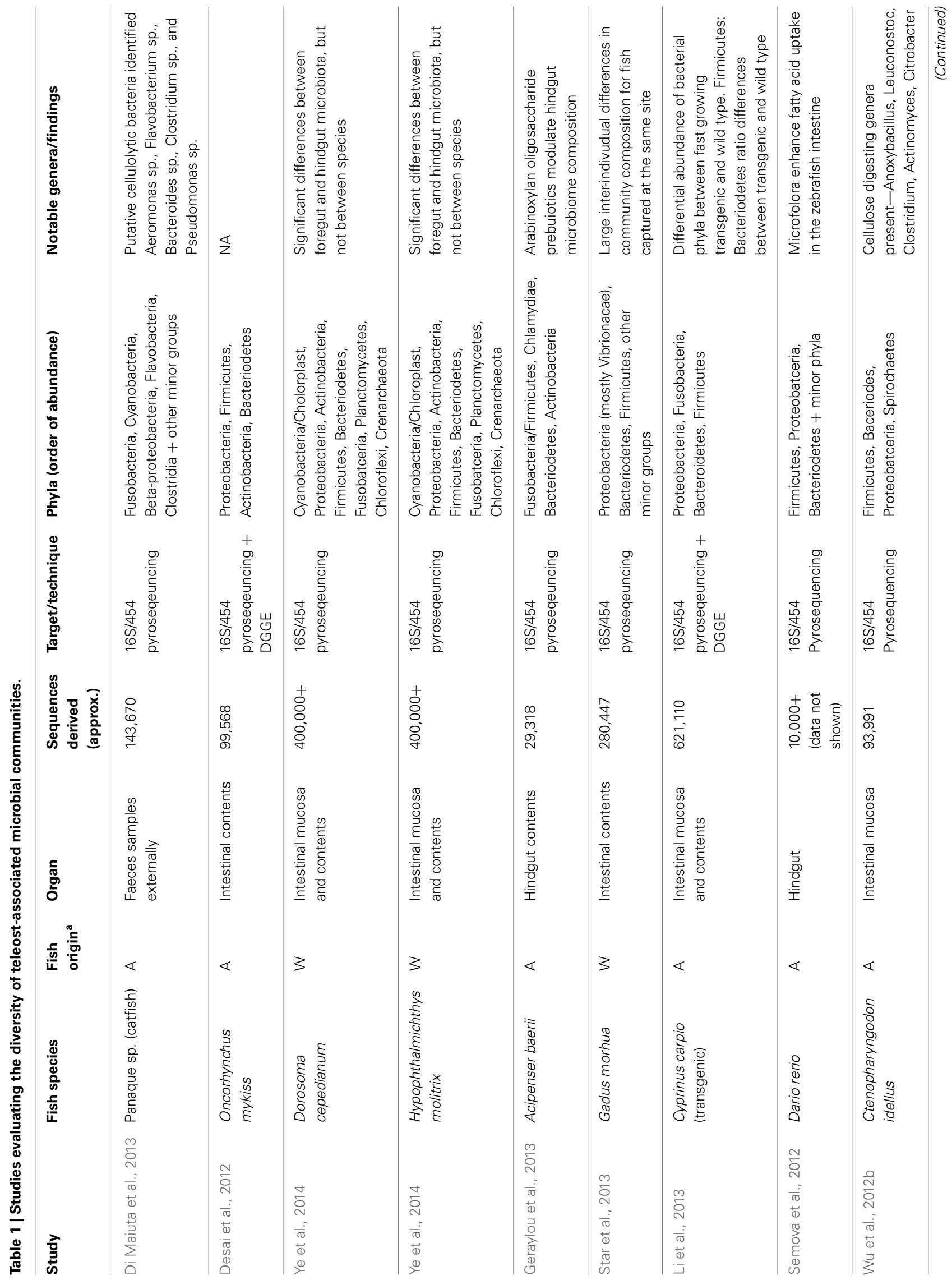




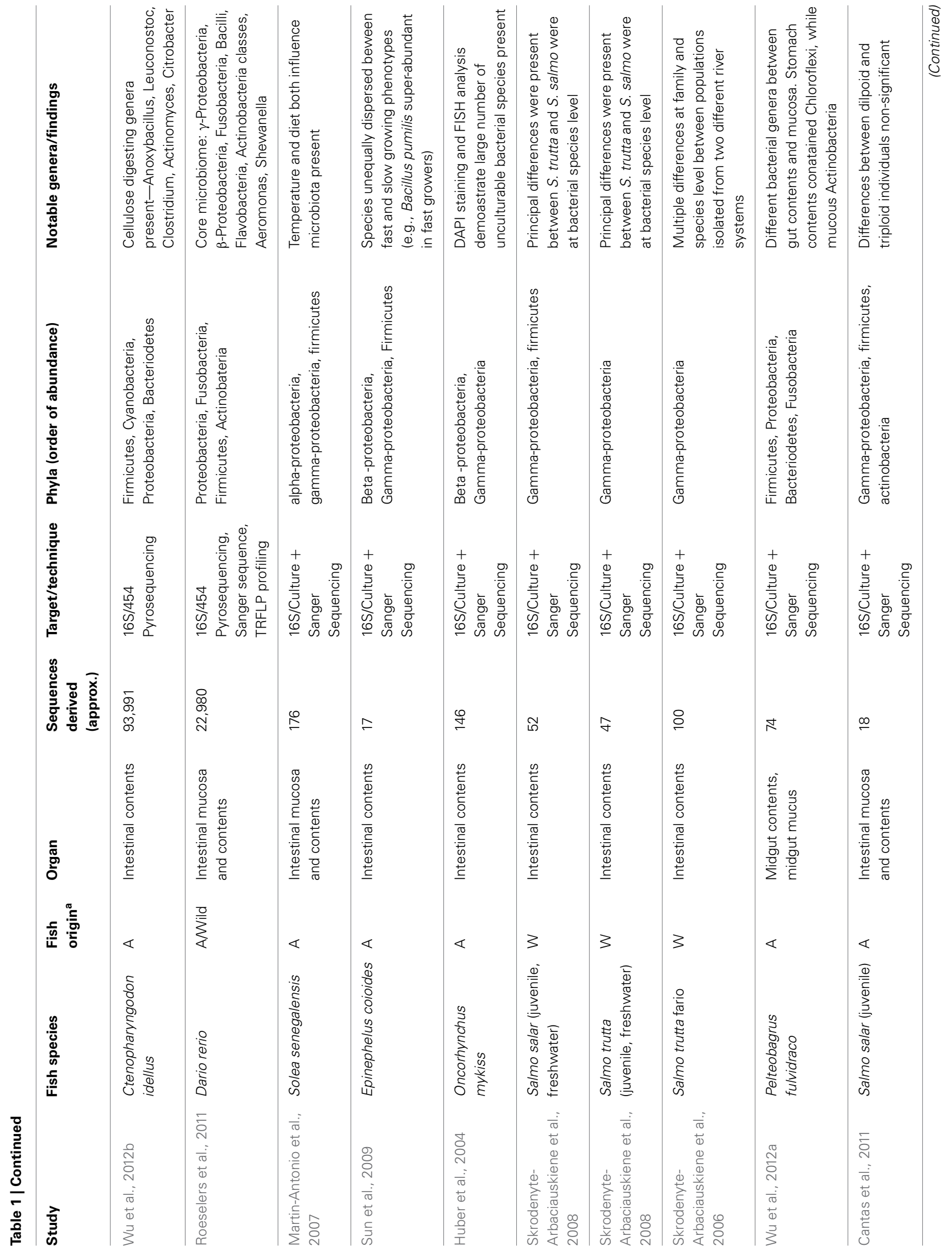



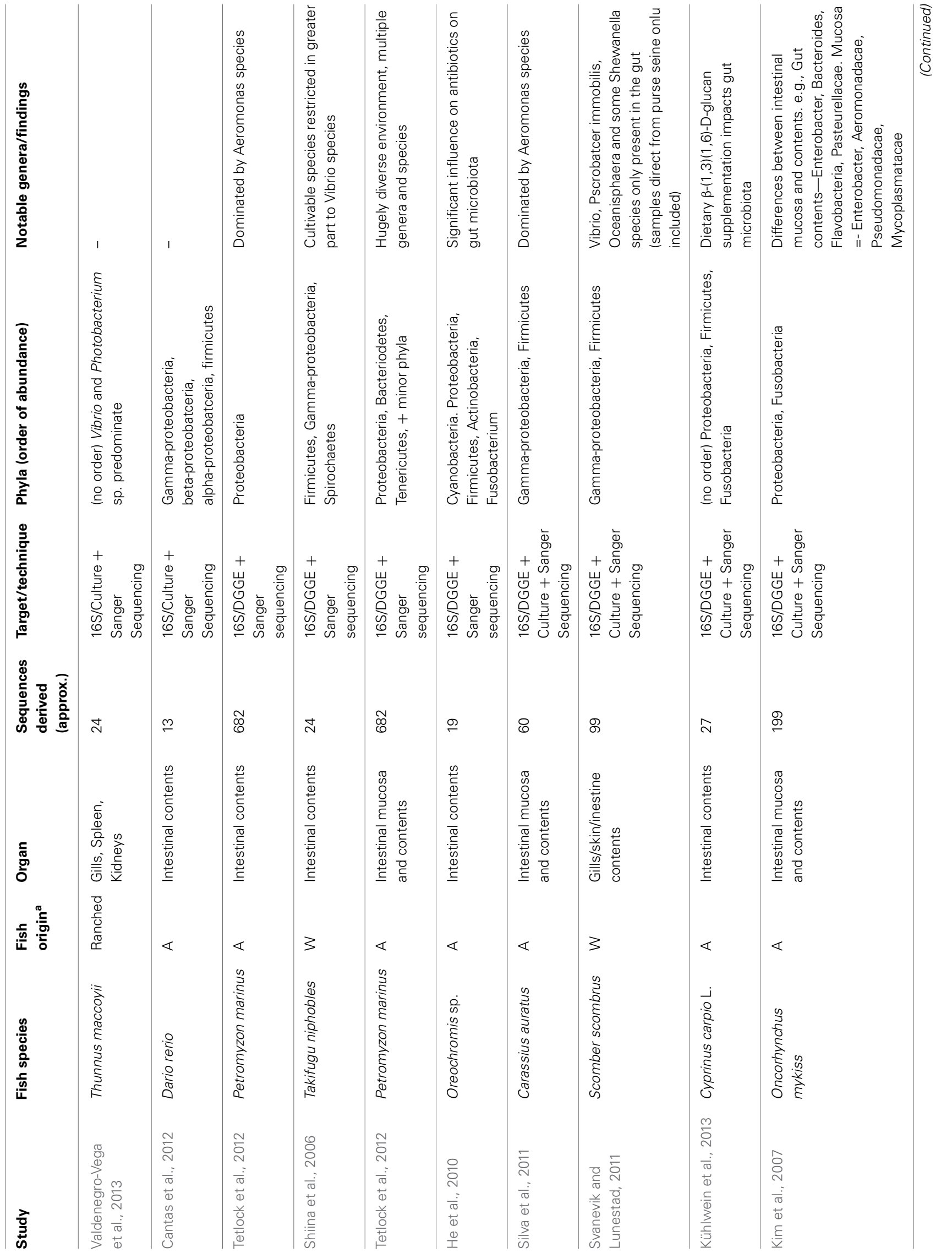

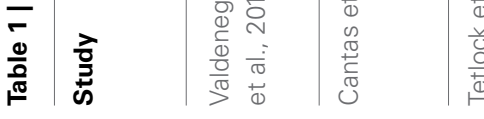




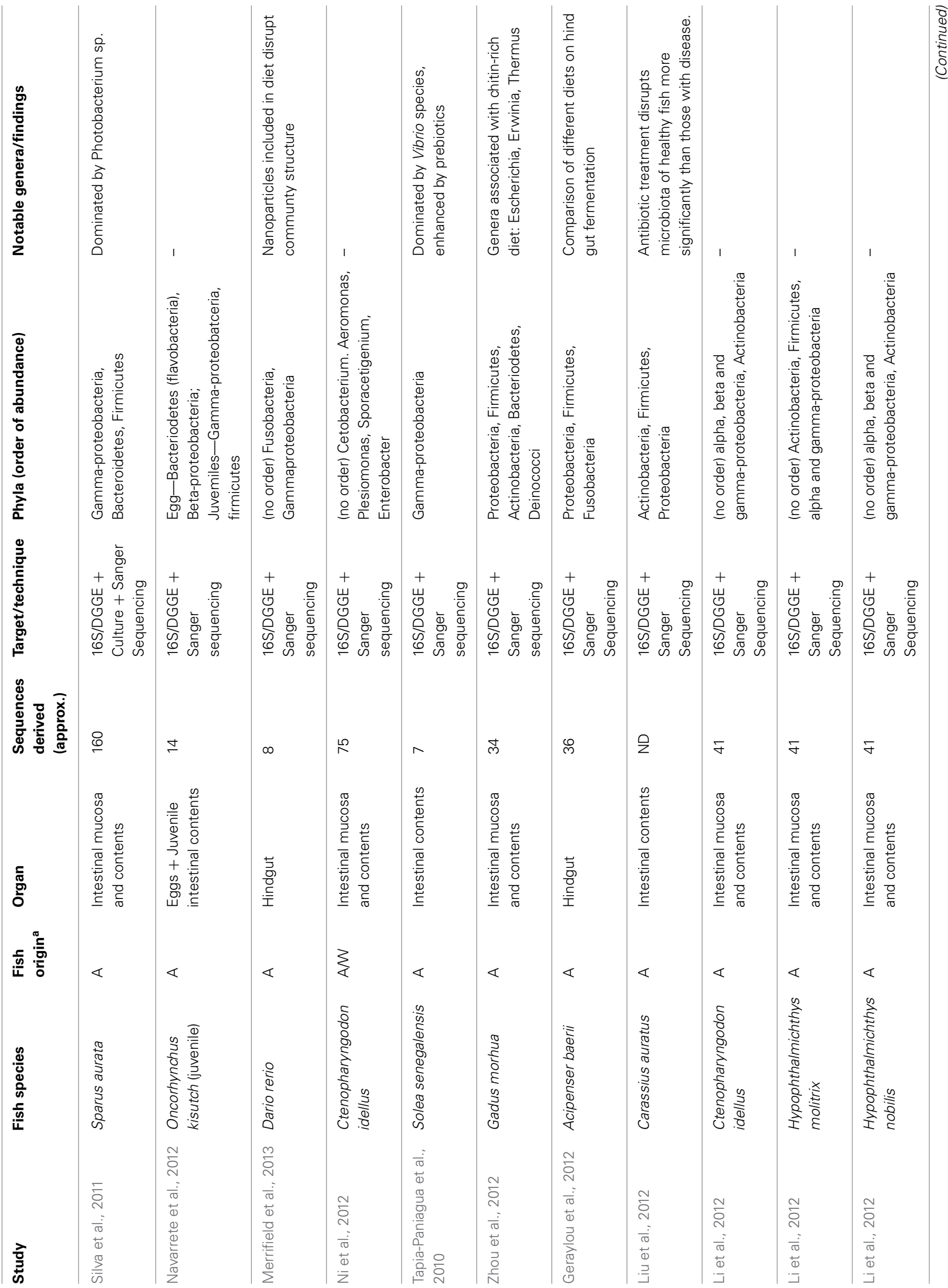




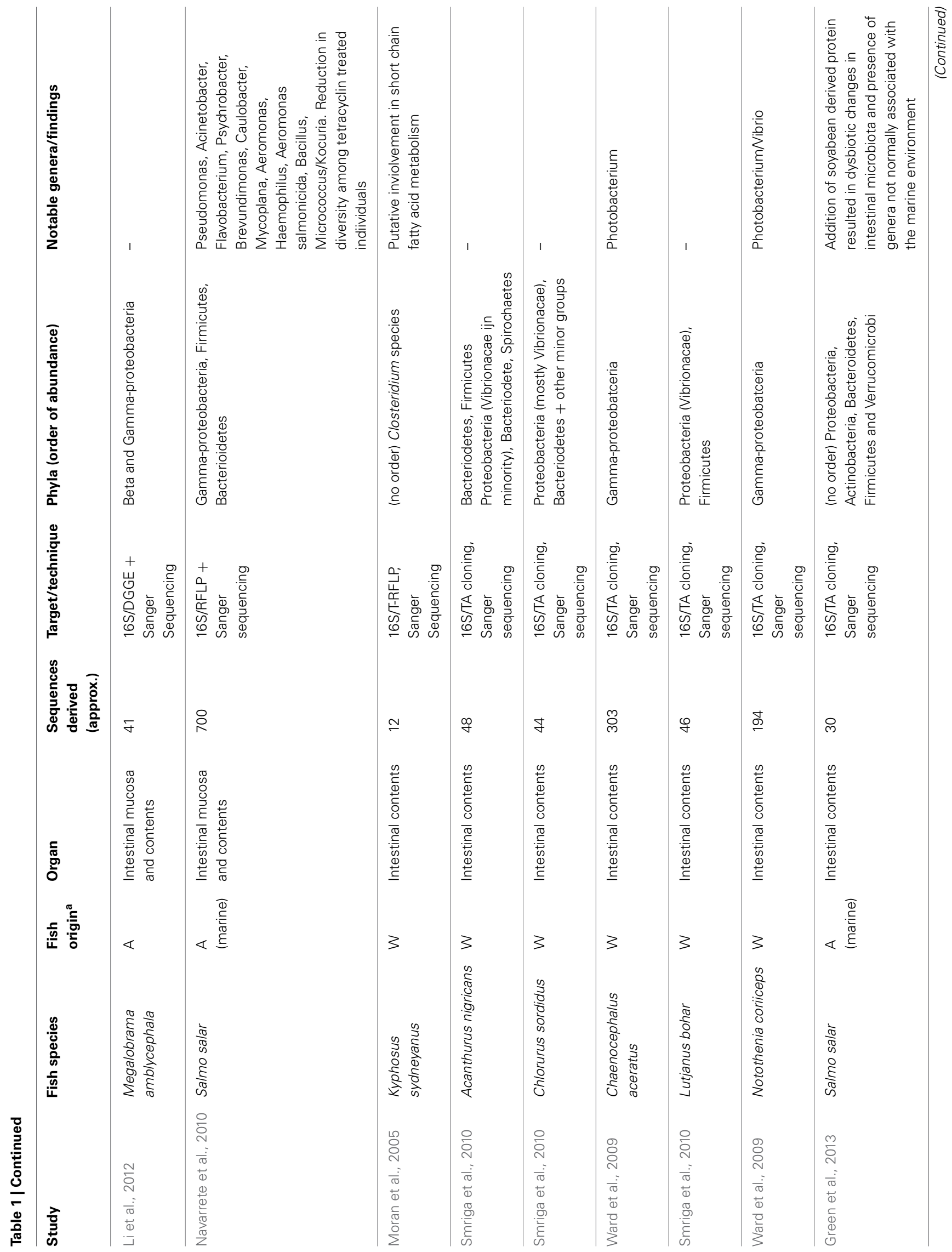




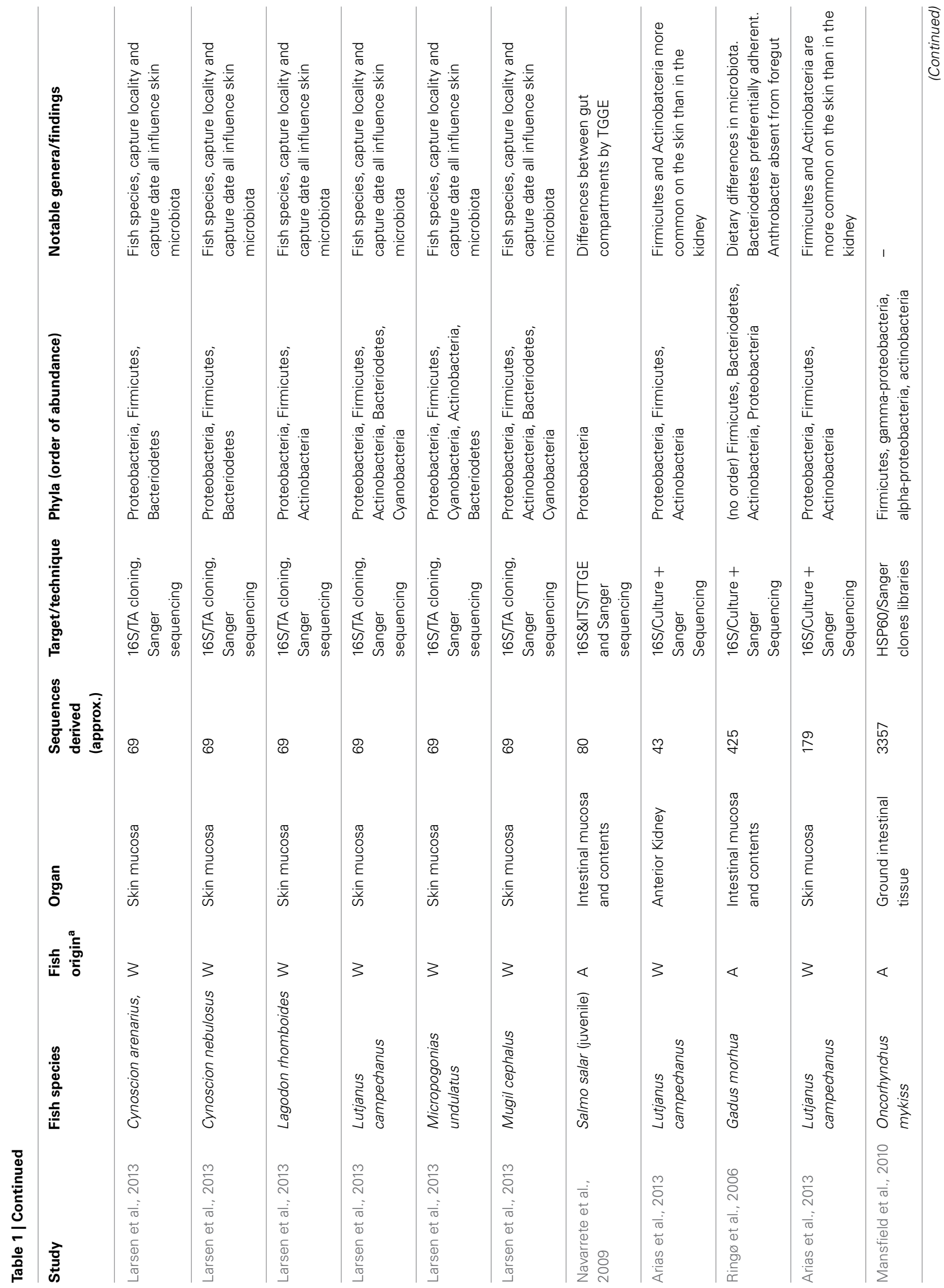




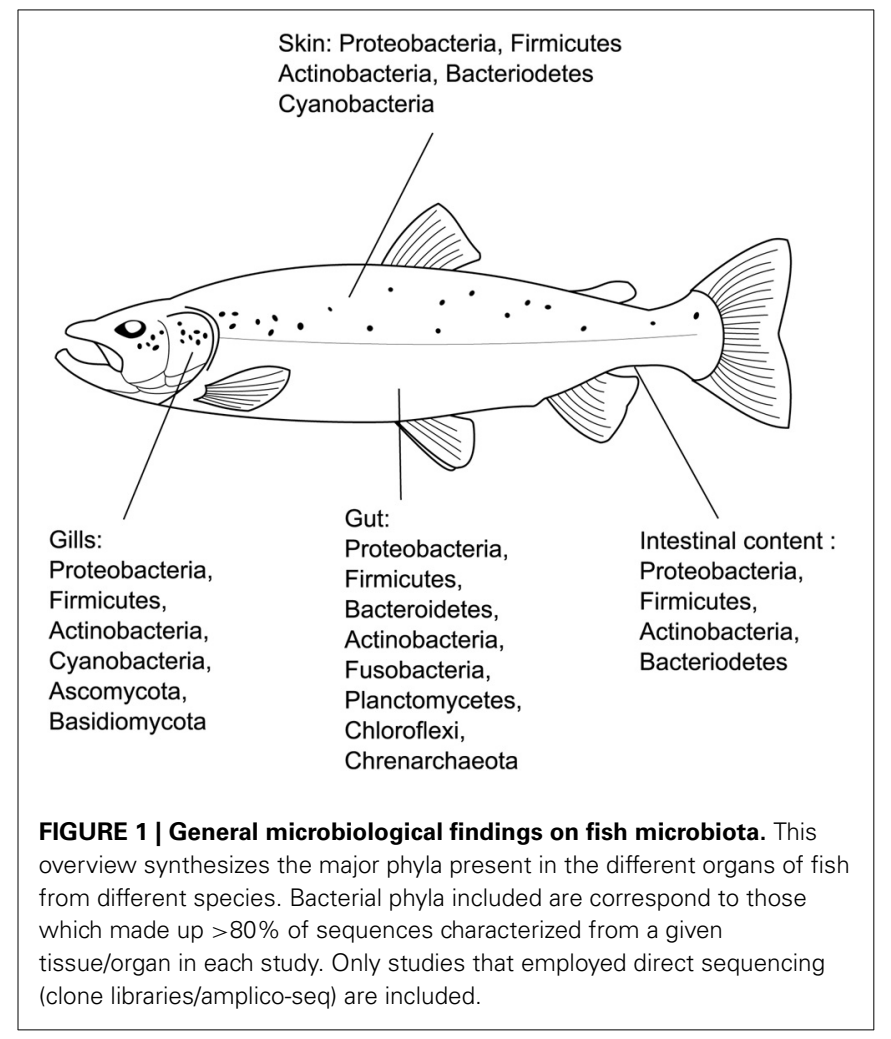

Yersinia, Renibacterium, and Mycobacterium (Austin and Austin, 2007). Most of these organisms can survive as well as (in some cases) replicate outside their host in the aquatic milieu. In addition they are almost all opportunistic pathogens (Austin and Austin, 2007). Culture and direct sequencing based surveys of commensal skin and intestinal microbiota suggest bacterial pathogens frequently occur as a minor component of healthy teleost microbiomes but emerge as pathogens under certain circumstances, e.g., (Navarrete et al., 2010; Austin and Austin, 2012; Boutin et al., 2013a,b). Stress, usually of the prolonged, maladaptive type, is perhaps the most commonly attributed as a causal factor in aquaculture disease outbreaks (Snieszko, 1974; Wakabayashi, 1991; Wendelaar Bonga, 1997; Le Moullac et al., 1998; Sudo et al., 2004; Schimel et al., 2007; Freestone et al., 2008; O’Mahony et al., 2009; Thurber et al., 2009; Littman et al., 2010; Boutin et al., 2012; Verbrugghe et al., 2012; Moloney et al., 2013). The link between stress and disease is not limited to bacterial pathogens and teleost aquaculture. White spot syndrome virus (WSSV), for example, a major pathogen in shrimp, is commonly found in healthy populations as a commensal agent, yet the mechanisms for this latency are not clearly understood (Sanchez-Paz, 2010).

As aquaculture intensifies, host population densities have increased to support the kind of virulence shifts associated with pathogenic agents that cause large, horizontally transmitted outbreaks (Pulkkinen et al., 2010). Stress-induced microbiome dysbiosis may be a useful predictor for the emergence of opportunistic disease. However, it is not clear to what extent a healthy microbiome will protect against the more virulent aquaculture pathogens of the future. Furthermore, it remains to be 

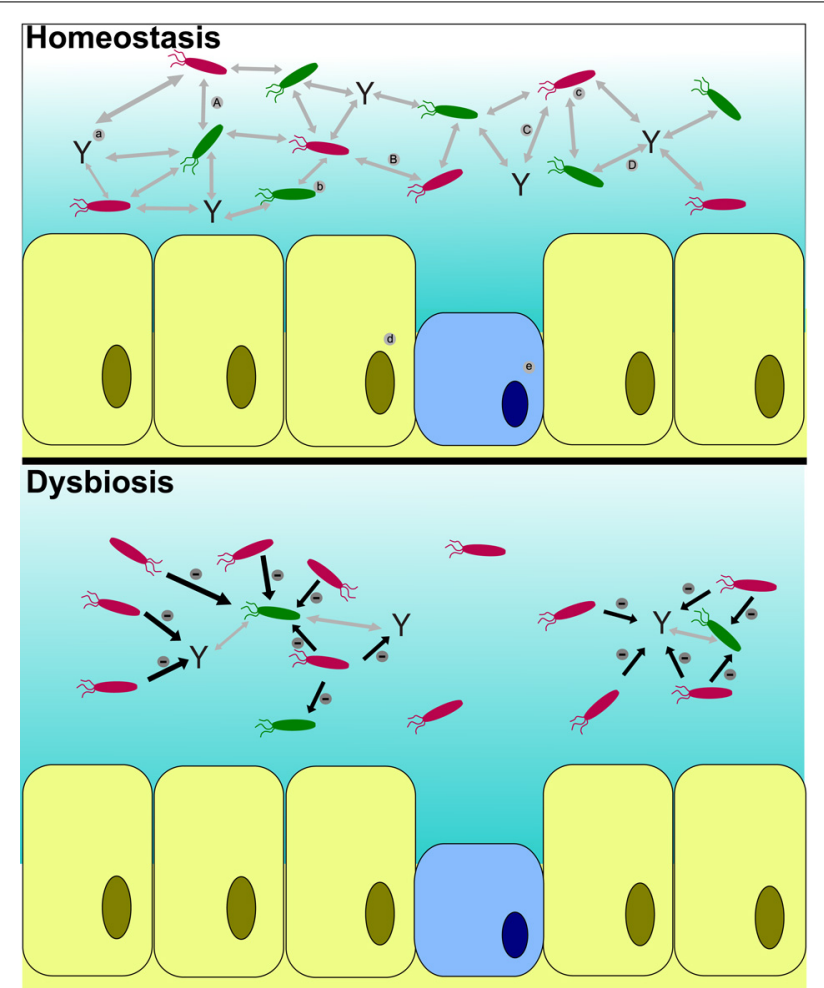

FIGURE 2 | Host microbiota interactions during homeostasis and dysbiosis. The host is able to control the pathogen (c) growth by different process $(A, C)$ involving the immune response (a) and the resident microbiota (b). Furthermore, the immune response recognizes the resident microbiota (D) as non-pathogenic bacteria. Pathogenic bacteria auto-regulate abundance via quorum sensing $(B)$ and can detect environmental signals from host cells [epidermic cells (d) and mucous cells (e)]. During dysbiosis, the pathogenic population, triggered by the stress response of the host (diminution of the immune response, production of mucus and diminution of the abundance of the resident microbiota), overcome the immune response and outcompete the resident microbiota.

seen what role the teleost microbiomes have in defining susceptibility to important ectoparasites in aquaculture (Caligidae, Monogea, etc.), as well as to the secondary bacterial infections they precipitate.

\section{DIET AND THE TELEOST MICROBIOME}

Most published work on teleost-associated microbiota focuses on the intestinal microbiome (Table 1). Among those experimental studies undertaken, a common line of investigation is the influence of diet on bacterial community composition. Nonmarine protein supplementation is a key issue with respect to the aquaculture of predatory marine teleosts. For both Salmo salar and Gadus morhua supplementation with soya bean derived proteins resulted in significant shifts in intestinal microbiota, including the presence of bacteria atypical to marine environments (Ringø et al., 2006; Green et al., 2013). It is not clear whether these changes may be termed "dysbiotic" as the authors suggest, partly because so little is known about the "natural" state of gut microbiomes in these species. Fortunately recent work has probed the natural diversity of gut microbiota in wild Norweigian cod (G. morhua) via Roche 454 pyrosequencing (Star et al., 2013). The study revealed substantial inter-individual variation and suggested a predominance of Vibrionacae (proteobacteria) among the $15+$ bacterial orders identified. Meaningful comparison between this dataset and previous, culture based surveys of microbiota in G. morhua are essentially impossible, although proteobacteria were been identified using both isolation techniques (Ringø et al., 2006; Zhou et al., 2012). The current technological shift from culture-based isolation and Sanger sequencing to direct PCR amplification and massively parallel sequencing means that meaningful comparisons are thin on the ground. The total number of bacterial sequences derived from G. morhua intestinal microbiomes was 459 prior to Star et al. (2013) (Ringø et al., 2006; Zhou et al., 2012; Star et al., 2013). The pyrosequencing Star et al. (2013) undertook increased this tally by 280,447 .

Whether or not teleost microbial studies have used the most up-to-date methods for profiling gut bacterial communities, the themes on which they touch are certainly valid, and form a platform for future research. As well investigating the impact of soya protein, researchers have evaluated the impact of dietary chitin on the microbiome (Zhou et al., 2012). Chitin represents a huge, but largely indigestible, potential source of carbohydrates for fish. It is of considerable interest what role indigenous gut microbiota might play in chitin decomposition. Similarly, the presence of cellulolytic microbial species in the intestines of the wood eating catfish has been probed (Di Maiuta et al., 2013). Such studies will benefit from functional characterization of the bacterial metagenetic repertoire, and teleost alimentary tracts promise rich veins for glycide hydrolase bioprospecting, given the huge variety of different dietary niches they exploit.

\section{MICROBIOME MANIPULATION PROBIOTICS}

It is understood that several parameters: genetic, nutritional and environmental; affect the abundance and diversity of gut microbiota in fish (Dimitroglou et al., 2011; Daniels and Hoseinifar, 2014; Ring $\varnothing$ et al., 2014). The idea of manipulating gut microbiota of fish developed as a consequence of the fact that potentially beneficial bacterial communities such as lactic acid bacteria naturally constitute only a minor proportion of intestinal microbiota of fish or shellfish (Ringø et al., 2010). It has been suggested that the manipulation of fish gut microbiota will result in elevation of resistance against pathogens, growth enhancement, improved lipid metabolism, stimulation of immune response and better physiological status for the gut (Tellez et al., 2006). Thus, there is increasing interest in strategies for the manipulation of gut microbiota of fish toward beneficial communities (e.g., lactic acid bacteria) (Daniels and Hoseinifar, 2014; Ringø et al., 2014).

A primary approach toward microbiome manipulations is the administration of probiotics, which are defined as live microbial culture added to feed or environment (water) to increase viability (survival) of the host (Gram and Ringø, 2005). This definition is being constantly refined and updated associated with health promoting properties (Irianto and Austin, 2002a) or with other benefits. The latest accepted definition for probiotics for aquatic animals is suggested by Merrifield et al. (2010). According to the authors probiotic for aquaculture is a live, dead or component 
of a microbial cell that, when administered via the feed or to the rearing water, benefits the host by improving either disease resistance, health status, growth performance, feed utilization, stress response, which is achieved at least in part via improving the hosts or the environmental microbial balance.

Although the mechanisms by which probiotics exert their beneficial effects on the host are largely unknown, probiotics administration showed promising results on growth performance and health of teleost fish (Gatesoupe et al., 2010). Despite the aforementioned advantages of probiotics, the viability of live bacteria during large-scale production of food (i.e., commercial diets) and during transition through the gastrointestinal tract is not reliable (Ringø et al., 2014).

\section{PREBIOTICS}

To resolve issues with probiotics, the prebiotic concept has been suggested and developed (Mahious and Ollevier, 2005). A prebiotic is a non digestible food ingredient that beneficially affects the host by selectively stimulating the growth and/or activity of one or a limited number of bacteria in the colon, that can improve the host health (Roberfroid, 2007). According to Gibson (2004) a dietary ingredient should meet the following criteria to be classified as a prebiotic, (1) resist gastric acidity, hydrolysis by digestive enzymes and gastrointestinal absorption; (2) be fermented by the intestinal microbiota and; (3) be able to selectively stimulate the growth and activity of beneficial bacteria (Gibson, 2004). To our knowledge the first study on prebiotics in aquaculture was reported by Hanley et al. (1995). Since then the most common prebiotics studied in fish were inulin, fructooligosaccharides (FOS), short-chain fructooligosaccharides (scFOS), mannanoligosaccharides (MOS), trans-galacto-oligosaccharides (TOS), Bio-MOS ${ }^{\circledR}$ containing MOS derived from yeast, galacto-oligosaccharides (GOS), xylooligosaccharides (XOS), arabinoxylooligosaccharides (AXOS), isomaltooligosaccharides (IMO), GroBiotic ${ }^{\circledR}$-A (GBA) (Ringø et al., 2014). Beneficial bacterial members of the gut microbiota use prebiotics as substrate for growth. 454 pyrosequencing has recently confirmed this effect in juvenile Siberian sturgeon (Acipenser baerii) fed with an AXOS prebiotic (Geraylou et al., 2012). In this work, significant increases in abundance of several bacterial families, including Lactobacillaceae, were observed in individuals with AXOS treatment regimes. Another important product of prebiotic fermentation by gut microbiota is short chain fatty acid (SCFA) (Cummings and Macfarlane, 2002). SCFA are the main energy source for colonic epithelial cells and thus associated with maintenance of the epithelium (Maslowski and Mackay, 2010). Moreover, it has been proposed that SCFA modulates lipid synthesis (Marcil et al., 2002) and has the potential to stimulate the immune system and resistance against pathogens (Maslowski and Mackay, 2010). However, it remains to be seen precisely which microbial taxa play a dominant role in SCFA production in fish.

\section{SYNBIOTICS}

A recent concept in regards to the manipulation of gut microbiota are synbiotics. Synbiotics refer to nutritional supplements combining probiotics and necessary nutrients for their survival
(Cerezuela et al., 2011). As such, synbiotics aim to simultaneously seed and maintain probiotic strains as the dominant species in the gut after treatment cessation (Rurangwa et al., 2009). Despite recent progress in the field of synbiotics administration in aquaculture, there is limited information available on different aspects of synbiotics' effects on fish (Cerezuela et al., 2011).

\section{PROBIOTICS AND DISEASE}

The use of probiotics as biological control agents for disease is fairly well established in aquaculture, in contrast to other areas of animal and human health, where it seems all but absent as an approach (Newaj-Fyzul et al., 2013). Bacterial cultivars from over 30 different genera are have been administered (NewajFyzul et al., 2013). Target disease agents are usually bacterial, and infection with a wide variety of pathogens has been treated in several different teleost species, primarily in aquaculture. Aeromonas hydrophila has been successfully used in vivo to treat A. salmonicida infection in Oncorhynchus mykiss, for example (Irianto and Austin, 2002b). Meanwhile Rhodococcus qingshengii had been successfully applied to the treatment of Flavobacterium psychrophilum infection in Salevinus fontinalis (Boutin et al., 2012). There are numerous examples in the literature of such trials (Newaj-Fyzul et al., 2013), however, it is by no means clear by what mode of action these agents operate, especially in the context of the wider microbiome. While some effective probiotics, particularly those administered prior to challenge with the infectious agents, (e.g., De la Banda et al., 2012), may to an extent bolster the "colonization resistance" of the indigenous microbiome, the action of others is less clear still. Longitudinal surveys of the indigenous microbiome during these trials are sparse, and there is clearly significant scope for further research.

\section{HOST GENETICS AND TELEOST MICROBIOMES}

The level of influence that host genome exerts on microbiome composition is a matter for debate, even in well-studied organisms like humans (Spor et al., 2011). There is evidence that the quantitive trait loci (QTL) can detect an influence of host genetic variation on fecal microbiome composition in mice (Benson et al., 2010). Those taxa under host genetic control corresponded with species and genera thought to interact with host immunity (Benson et al., 2010). QTL analysis of skin microbiome composition has recently been undertaken in the salmonid Salvelinus fontinalis (Boutin et al., 2014) and "common garden experiments" on different O. mykiss families have also explored associations with host background (Navarrete et al., 2012). As with mice, in both cases there is some limited evidence for host genetic control. At the inter-species level, there may some level of hostspecificity in teleost larvae as well (Li et al., 2012). Given that maternal effects can be largely discounted in fish, the mechanism through which such control is exerted must be innate immunity. Pathogen Recognition Receptors (PRRs) - comprised of Toll-like receptors (TLRs), and their co-receptor CD14, the scavengers receptors, the mannose receptors, the integrins $\mathrm{CD} 11 \mathrm{~b}-\mathrm{c} / \mathrm{CD} 18$ and the complement receptors CR1,2,3-form a major component in innate immunity. PRRs are expressed at the surface of the cells to recognize a variety of non-host ligands collectively termed microbe associated molecular patterns (MAMPs) (Medzhitov and 
Janeway, 1999). Standing genetic variation among components of the teleost adaptive immune system is increasingly well characterized, (e.g., Dionne et al., 2009; Pavey et al., 2013). While TLRs are present in multiple teleost species (Palti, 2011), there has been no work to date to correlate genetic diversity at these innate immune loci (inter- or intra- species) with commensal microbiome diversity. Experiments in zebrafish highlight the role that TLRs play in modulating intestinal microbiota, whereby alkaline phosphatase is produced via a TLR-4-myD88 controlled pathway to inhibit an inflammatory responses to gut microbiota (Bates et al., 2007). Given that desirable microbiome characteristics from an aquaculture perspective may exist (e.g., disease resistance, nutrient absorption, stress resilience), it is encouraging that a host genetic basis may exist to select for such traits.

\section{MICROBIOME ONTOGENESIS}

Intensive aquaculture is hampered by unpredictable mortalities during early life stages that are likely due, at least in part, to negative interactions between fish larvae and some bacterial strains they routinely encounter. In order to control mortalities at early life stages, the aquaculture industry prioritized egg and larvae disinfection protocols. Such guidelines are perhaps counter-productive, given that most of the bacteria routinely isolated from hatcheries are not harmful to larvae (Verner-Jeffreys et al., 2003), and fish microbiota are the first line of defense against pathogens (Boutin et al., 2012).

Early promotion of nutrient metabolism and innate immune response depend upon the bacterial species that colonize the digestive tract. It is therefore of primary importance to understand the mechanisms that orchestrate the early steps of colonization of the gastrointestinal tract of fish, leading the buildup of a stable, diversified and resilient endogenous microbial community. Colonization steps are summarized in Figure 3.

Culture-based identification of bacterial species has been the mainstay of studies examining early teleost microbiome development to date, but their finding are nonetheless intriguing. In the aquatic environment, bacteria move easily between habitats and hosts. Thus the first steps of interactions and colonization of fish progeny occur as soon as the eggs are laid. The number of bacteria colonizing salmonid eggs, for example, ranges between $10^{3}$ and $10^{6}$ bacteria $\mathrm{g}^{-1}$ (Yoshimizu et al., 1980). The diverse microbiota that eventually develops on the egg surface is expected to reflect the bacterial composition of the water. Interestingly,
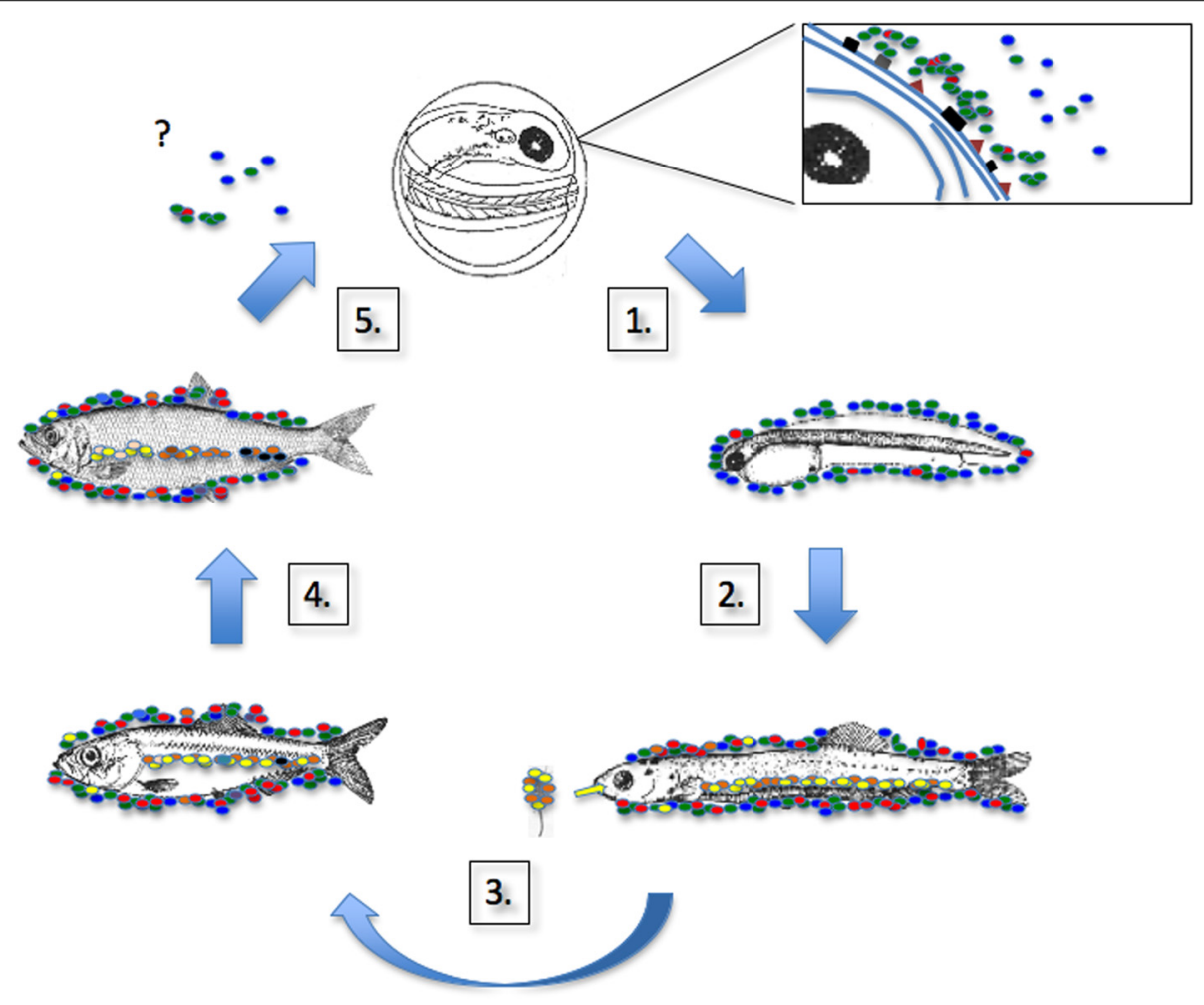

FIGURE 3 | Teleost microbiome during development. Figure shows schematic of the generalized lifecycle of a teleost and accessory indigenous bacteria (different taxa represented by colored elipses). (1) Bacteria colonize the chorion of the egg. Taxonomic differences of bacteria between fish species suggest specific early interactions, perhaps through precursors of innate immunity (symbolized by squares and triangles on the chorion surface). (2) Egg hatches, larval is colonized by environmental bacteria as well as those originally present on the chorion.
(3) Early digestive tract colonization occurs when larva commence feeding. Bacterial taxa strongly resemble those associated with food source. (4) Microbiome develops, accumulates diversity and matures. (5) Adult microbiome is diverse assemblage of microbial taxa. Differences exist between surface mucosal and intestinal communities. Intestinal communities also be compartmentalized/specialized to niches within the alimentary tract. Question mark indicates possible vertical transmission of microbiome components to eggs during oviposition. 
species-specific differences were observed in terms of bacterial colonization of fish eggs between cod and halibut (Hansen and Olafsen, 1989). Such host specific assemblages on the chorion may result from differential attraction to surface receptors, to those being coded by host genotype. Once eggs hatch, sterile larvae are rapidly colonized by ova debris and microbiota present in the environment (Hansen and Olafsen, 1989). Passage of surface bacteria into the gut is expected to colonize larvae gut as soon they are begin to ingest their liquid medium (Lauzon et al., 2010). Unsurprisingly, the alimentary tract of first-feeding fries is colonized with bacteria associated with food (Blanch et al., 1997; Korsnes et al., 2006; Reid et al., 2009). The process of recruitment of taxa to the developing microbiome clearly has to work with those bacteria present in the immediate environment.

Romero and Navarrete (2006) pioneered the identification of dominant bacterial populations associated with early life stages of salmon coho using a 16S RNA barcoding approach using a DGGE metagenomic (culture-independent) approach (Romero and Navarrete, 2006). They focused on three developmental stages (eggs, first-feeding fry, juvenile) and documented environmental bacterial communities (surrounding water, pelletized feed) in order to determine the putative origin of dominant intestine tract strains. Interestingly, a dominant Pseudomonas sp. found in the juvenile gastrointestinal tract was also present on eggs, but not in the water nor in food. This may suggests a vertical transmission of a pioneering strain, which is commonly observed as a dominant genus in gut microbiota of mature fish (Hansen and Olafsen, 1999; Jensen et al., 2004; Navarrete et al., 2010). Overall, DGGE profiles showed pioneering communities harboring very few ribotypes, those encountered important shifts, at least in terms of taxonomic diversity, between eggs, first-feeding fry, and juvenile step. The authors concluded that the early steps of the gut microbiota colonization by bacterial strains do not reflect a stable microbiota, which would be established after the first feeding stages, by recruiting its major components from water and prey epibiota. Such finding corroborates the observation that during the initial stage of gut colonization, microbiota is highly unstable in humans (Palmer et al., 2007; Mariat et al., 2009; Cho and Blaser, 2012) and mice (El Aidy et al., 2012, 2013). Furthermore, the temporal pattern in which gut microbiota evolves is characterized by a remarkable interindividual variation. Over time, microbial groups that typically dominate the adult intestinal microbiota overcome the early-colonizing microbes that are less adapted to the intestinal environment (Palmer et al., 2007; El Aidy et al., 2013).

Because the early stages of fish development are the most sensitive regarding to outbreak caused by opportunistic pathogens, and because fish microbiota are now understood as the very first barrier against opportunistic pathogens, it is of primary importance to identify the factors that control the early steps of colonization of the fish microbiota, in order to maximize the rearing conditions leading to the buildup of a stable, diversified and resilient endogenous microbial community. Gnotobiotic models starting with germ-free larvae provide an excellent tool to disentangle accurately the host microbe interactions (Rawls et al., 2004, 2006; Dierckens et al., 2009; Rekecki et al., 2013; Rendueles et al., 2013). For example zebrafish (Danio rerio), a widely used cyprinid fish as a valuable vertebrate developmental model, proved to be convenient for studying gut microbiota ontogenesis, hostmicrobiota and host-pathogen interactions (Rawls et al., 2004, 2006; Kanther, 2010). Thus, far, more than 20 pathogenic strains have been tested on germ free zebrafish (van der Sar et al., 2004; Lesley and Ramakrishnan, 2008; Kanther, 2010; Kanwal et al., 2013) or colonized with an artificial microbiota (Rawls et al., 2006; Cheesman and Guillemin, 2007; Kanther et al., 2011). Similar experiments were undertaken in non-model fish such as cod (Forberg et al., 2012), sea bass (Rekecki et al., 2013), and halibut (Verner-Jeffreys et al., 2003). In general, the results from most studies involving challenge of wild type or germ-free fish larvae with opportunistic pathogens highlight the protective role of the indigenous bacteria (Kanwal et al., 2013; Rendueles et al., 2013).

\section{CONCLUSIONS}

At the time of writing, teleost microbiome research is on the cusp of significant progress. Next generation sequencing is increasable affordable, computationally achievable in small laboratories, and generally accessible to the wider scientific community outside model vertebrates. In this review we have highlighted areas of current interest for teleost microbiome research, namely as biomarkers for stress and disease resistance. Diet is also a major area for microbiome research, especially with regards to new feed sources to mitigate the environmental impact of aquaculture. We discussed current approaches to directly manipulate host microbiomes via pro-, pre- and synbiotics in an attempt to improve fish condition and treat disease, as well as a host genetic basis for microbiome diversity, which could be used to select for desirable microbiome traits in the future. Finally we touched on microbiome ontogenisis in juvenile fish, crucial for the development healthy digestion and immunity.

Whilst the areas of research interest have largely been defined, the technology will shortly shift. Once next generation sequencing is routinely used to characterize teleost microbiomes, it should become significantly easier to make meaningful comparisons between species, studies, research centers and sample sites. In line with approaches defined by the HMP (Human Microbiome Project, 2012), it is extremely important to establish baselines for natural teleost microbiomes before meaningful conclusions can be drawn from the same species in aquaculture. The term "dysbiosis" is currently over-used given that the natural stability (or instability) of any teleost microbiome is not currently known.

The next 5-10 years will be an exiting time for teleost microbiome research. The timing couldn't be better given the parlous state or many wild fish stocks, the increasing global demand for fish protein, and the need to find sustainable approaches to improve aquaculture yield and mitigate its impact on marine and freshwater environments.

\section{ACKNOWLEDGMENTS}

The authors would like to thank the editor D. G. Biron and two anonymous reviewers for their exceedingly useful critical input. Nicolas Derome is funded by an NSERC Discovery Grant, Sébastien Boutin by NSERC CREATE and Martin S. Llewellyn by a Marie-Curie international outgoing fellowship - FISHPROBIO. 


\section{REFERENCES}

Arias, C. R., Koenders, K., and Larsen, A. M. (2013). Predominant bacteria associated with red snapper from the Northern Gulf of Mexico. J. Aquat. Anim. Health 25, 281-289. doi: 10.1080/08997659.2013.847872

Ashley, P. J. (2007). Fish welfare: current issues in aquaculture. Appl. Anim. Behav. Sci. 104, 199-235. doi: 10.1016/j.applanim.2006.09.001

Austin, B., and Austin, D. (2012). Aeromonadaceae Representative (Aeromonas salmonicida). Bacterial Fish Pathogens. (Netherlands: Springer), 147-228.

Austin, B., and Austin, D. A. (2007). Bacterial Fish Pathogens: Diseases of Farmed and Wild Fish. Dordrecht; Chichester: Praxis Publishing Ltd.

Balcazar, J., Blas, I., Ruizzarzuela, I., Cunningham, D., Vendrell, D., and Muzquiz, J. (2006). The role of probiotics in aquaculture. Vet. Microbiol. 114, 173-186. doi: 10.1016/j.vetmic.2006.01.009

Barton, B. A., and Iwama, G. K. (1991). Physiological changes in fish from stress in aquaculture with emphasis on the response and effects of corticosteroids. Annu. Rev. Fish Dis. 1, 3-26. doi: 10.1016/0959-8030(91)90019-G

Bates, J. M., Akerlund, J., Mittge, E., and Guillemin, K. (2007). Intestinal alkaline phosphatase detoxifies lipopolysaccharide and prevents inflammation in zebrafish in response to the gut microbiota. Cell Host Microbe 2, 371-382. doi: 10.1016/j.chom.2007.10.010

Benson, A. K., Kelly, S. A., Legge, R., Ma, F., Low, S. J., Kim, J., et al. (2010). Individuality in gut microbiota composition is a complex polygenic trait shaped by multiple environmental and host genetic factors. Proc. Natl. Acad. Sci. U.S.A. 107, 18933-18938. doi: 10.1073/pnas.1007028107

Blanch, A., Alsina, M., Simon, M., and Jofre, J. (1997). Determination of bacteria associated with reared turbot (Scophthalmus maximus) larvae. J. Appl. Microbiol. 82, 729-734. doi: 10.1046/j.1365-2672.1997.00190.x

Boutin, S., Audet, C., and Derôme, N. (2013a). Probiotic treatment by indigenous bacteria decreases mortality without disturbing the natural microbiota of Salvelinus fontinalis. Can. J. Microbiol. 59, 662-670. doi: 10.1139/cjm2013-0443

Boutin, S., Bernatchez, L., Audet, C., and Derôme, N. (2012). Antagonistic effect of indigenous skin bacteria of brook charr (Salvelinus fontinalis) against Flavobacterium columnare and F.psychrophilum. Vet. Microbiol. 155, 355-361. doi: 10.1016/j.vetmic.2011.09.002

Boutin, S., Bernatchez, L., Audet, C., and Derome, N. (2013b). Network analysis highlights complex interactions between pathogen, host and commensal microbiota. PLoS ONE 8:e84772. doi: 10.1371/journal.pone.0084772

Boutin, S., Sauvage, C., Bernatchez, L., Audet, C., and Derome, N. (2014). Inter-individual variations of the fish skin microbiota: host genetics basis of mutualism? PLoS ONE. (in press).

Cantas, L., Fraser, T. W., Fjelldal, P. G., Mayer, I., and Sorum, H. (2011). The culturable intestinal microbiota of triploid and diploid juvenile Atlantic salmon (Salmo salar)_ a comparison of composition and drug resistance. BMC Vet. Res. 7:71. doi: 10.1186/1746-6148-7-71

Cantas, L., Sorby, J. R., Alestrom, P., and Sorum, H. (2012). Culturable gut microbiota diversity in zebrafish. Zebrafish 9, 26-37. doi: 10.1089/zeb.2011.0712

Cerezuela, R., Meseguer, J., and Esteban, M. (2011). Current knowledge in synbiotic use for fish aquaculture: a review. J. Aquac. Res. Dev. 1, 1-7. doi: 10.4172/21559546.S1-008

Cheesman, S., and Guillemin, K. (2007). We know you are in there: conversing with the indigenous gut microbiota. Res. Microbiol. 158, 2-9. doi: 10.1016/j.resmic.2006.10.005

Cho, I., and Blaser, M. (2012). The human microbiome: at the interface of health and disease. Nat. Rev. Genet. 13, 260-270. doi: 10.1038/nrg3182

Costello, E. K., Lauber, C. L., Hamady, M., Fierer, N., Gordon, J. I., and Knight, R. (2009). Bacterial community variation in human body habitats across space and time. Science 326, 1694-1697. doi: 10.1126/science.1177486

Cummings, J. H., and Macfarlane, G. T. (2002). Gastrointestinal effects of prebiotics. Br. J. Nutr. 87, S145-S151. doi: 10.1079/BJN/2002530

Daniels, C., and Hoseinifar, S. H. (2014). "Prebiotic applications in shellfish," in Aquaculture Nutrition: Gut Health, Probiotics and Prebiotics, Edn 1, eds D. L. Merrifield and E. Ringø (Hoboken, NJ: Wiley-Blackwell Scientific Publication).

De la Banda, I. G., Lobo, C., Chabrillon, M., Leon-Rubio, J. M., Arijo, S., Pazos, G., et al. (2012). Influence of dietary administration of a probiotic strain Shewanella putrefaciens on Senegalese sole (Solea senegalensis, Kaup 1858 ) growth, body composition and resistance to Photobacterium damselae subsp. piscicida. Aquac. Res. 43, 662-669. doi: 10.1111/j.1365-2109.2011. 02871.x
Desai, A. R., Links, M. G., Collins, S. A., Mansfield, G. S., Drew, M. D., Van Kessel, A. G., et al. (2012). Effects of plant-based diets on the distal gut microbiome of rainbow trout (Oncorhynchus mykiss). Aquaculture 350-353, 134-142. doi: 10.1016/j.aquaculture.2012.04.005

Dierckens, K., Rekecki, A., Laureau, S., Sorgeloos, P., Boon, N., Van den Broeck, W., et al. (2009.). Development of a bacterial challenge test for gnotobiotic sea bass (Dicentrarchus labrax) larvae. Environ. Microbiol. 11, 526-533. doi: 10.1111/j.1462-2920.2008.01794.x

Di Maiuta, N., Schwarzentruber, P., Schenker, M., and Schoelkopf, J. (2013). Microbial population dynamics in the faeces of wood-eating loricariid catfishes. Lett. Appl. Microbiol. 56, 401-407. doi: 10.1111/lam.12061

Dimitroglou, A., Merrifield, D. L., Carnevali, O., Picchietti, S., Avella, M., Daniels, C., et al. (2011). Microbial manipulations to improve fish health and production-a Mediterranean perspective. Fish Shellfish Immunol. 30, 1-16. doi: 10.1016/j.fsi.2010.08.009

Dionne, M., Miller, K. M., Dodson, J. J., and Bernatchez, L. (2009). MHC standing genetic variation and pathogen resistance in wild Atlantic salmon. Philos. Trans. R. Soc. Lond. B Biol. Sci. 364, 1555-1565. doi: 10.1098/rstb. 2009.0011

Dixon, D. R., Bainbridge, B. W., and Darveau, R. P. (2004). Modulation of the innate immune response within the periodontium. Periodontol. $200035,53-74$. doi: 10.1111/j.0906-6713.2004.003556.x

Easy, R. H., and Ross, N. W. (2009). Changes in Atlantic salmon (Salmo salar) epidermal mucus protein composition profiles following infection with sea lice (Lepeophtheirus salmonis). Comp. Biochem. Physiol. Part D Genomics Proteomics 4, 159-167. doi: 10.1016/j.cbd.2009.02.001

El Aidy, S., van Baarlen, P., Derrien, M., Lindenbergh-Kortleve, D., Hooiveld, G., Levenez, F., et al. (2012). Temporal and spatial interplay of microbiota and intestinal mucosa drive establishment of immune homeostasis in conventionalized mice. Mucosal Immunol. 5, 567-579. doi: 10.1038/mi.2012.32

El Aidy, S., Van den Abbeele, P., Van de Wiele, T., Louis, P., and Kleerebezem, M. (2013). Intestinal colonization: how key microbial players become established in this dynamic process: microbial metabolic activities and the interplay between the host and microbes. Bioessays 35, 913-923. doi: 10.1002/bies. 201300073

Espelid, S., LØKken, G. B., Steiro, K., and BØGwald, J. (1996). Effects of cortisol and stress on the immune system in Atlantic Salmon (Salmo salar). Fish Shellfish Immunol. 6, 95-110. doi: 10.1006/fsim.1996.0011

FAO. (2010). The State of World Fisheries and Aquaculture. Rome: FAO.

Forberg, T., Vestrum, R., Arukwe, A., and Vadstein, O. (2012). Bacterial composition and activity determines host gene-expression responses in gnotobiotic Atlantic cod (Gadus morhua) larvae. Vet. Microbiol. 157, 420-427. doi: 10.1016/j.vetmic.2012.01.007

Freestone, P. P., Sandrini, S. M., Haigh, R. D., and Lyte, M. (2008). Microbial endocrinology: how stress influences susceptibility to infection. Trends Microbiol. 16, 55-64. doi: 10.1016/j.tim.2007.11.005

Furusawa, Y., Obata, Y., Fukuda, S., Endo, T. A., Nakato, G., Takahashi, D., et al. (2013). Commensal microbe-derived butyrate induces the differentiation of colonic regulatory $\mathrm{T}$ cells. Nature 504, 446-450. doi: 10.1038/ nature 12721

Gatesoupe, F. J. (2010). "Probiotics and other microbial manipulations in fish feeds: prospective health benefits," in Bioactive Foods in Promoting Health. Probiotics and Prebiotics, eds R. R. Watson and V. R. Preedy (San Diego, CA: Academic Press), 541-552.

Geraylou, Z., Souffreau, C., Rurangwa, E., D’Hondt, S., Callewaert, L., Courtin, C. M., et al. (2012). Effects of arabinoxylan-oligosaccharides (AXOS) on juvenile Siberian sturgeon (Acipenser baerii) performance, immune responses and gastrointestinal microbial community. Fish Shellfish Immunol. 33, 718-724. doi: 10.1016/j.fsi.2012.06.010

Geraylou, Z., Souffreau, C., Rurangwa, E., Maes, G. E., Spanier, K. I., Courtin, C. M., et al. (2013). Prebiotic effects of arabinoxylan oligosaccharides on juvenile Siberian sturgeon (Acipenser baerii) with emphasis on the modulation of the gut microbiota using 454 pyrosequencing. FEMS Microbiol. Ecol. 86, 357-371. doi: $10.1111 / 1574-6941.12169$

Gibson, G. R. (2004). Fibre and effects on probiotics (the prebiotic concept). Clin. Nutr. Suppl. 1, 25-31. doi: 10.1016/j.clnu.2004.09.005

Gómez, G. D., and Balcázar, J. L. (2008). A review on the interactions between gut microbiota and innate immunity of fish. FEMS Immunol. Med. Microbiol. 52, 145-154. doi: 10.1111/j.1574-695X.2007.00343.x 
Gram, L., and Ringø, E. (2005). "Prospects of fish probiotics," in Microbial Ecology of the Growing Animal, eds W. H. Holzapfel and P. J. Naughton (Amsterdam: Elsevier), 379-417.

Green, T. J., Smullen, R., and Barnes, A. C. (2013). Dietary soybean protein concentrate-induced intestinal disorder in marine farmed Atlantic salmon, Salmo salar is associated with alterations in gut microbiota. Vet. Microbiol. 166, 286-292. doi: 10.1016/j.vetmic.2013.05.009

Hanley, F., Brown, H., and Carberry, J. (1995). "First observations on the effects of mannan oligosaccharide added to the hatchery diets for warmwater Hybrid Red Tilapia," in Nutritional Biotechnology in the Feed and Food Industries: Proceedings of Alltech's 11th Annual Symposium (Lexington, KY).

Hansen, G., and Olafsen, J. (1989). Bacterial colonization of cod (Gadus morhua L.) and halibut (Hippoglossus hippoglossus) eggs in marine aquaculture. Appl. Environ. Microbiol. 55, 1435-1446.

Hansen, G., and Olafsen, J. (1999). Bacterial interactions in early life stages of marine cold water fish. Microb. Ecol. 38, 1-26. doi: 10.1007/s002489900158

He, S., Zhou, Z., Liu, Y., Cao, Y., Meng, K., Shi, P., et al. (2010). Effects of the antibiotic growth promoters flavomycin and florfenicol on the autochthonous intestinal microbiota of hybrid tilapia (Oreochromis niloticus $+\times$ O. aureus $\sigma^{7}$ ). Arch. Microbiol. 192, 985-994. doi: 10.1007/s00203-010-0627-z

Hooper, L. V., Littman, D. R., and Macpherson, A. J. (2012). Interactions between the microbiota and the immune system. Science 336, 1268-1273. doi: $10.1126 /$ science. 1223490

Huber, I., Spanggaard, B., Appel, K. F., Rossen, L., Nielsen, T., and Gram, L. (2004). Phylogenetic analysis and in situ identification of the intestinal microbial community of rainbow trout (Oncorhynchus mykiss, Walbaum). J. Appl. Microbiol. 96, 117-132. doi: 10.1046/j.1365-2672.2003.02109.x

Human Microbiome Project, C. (2012). Structure, function and diversity of the healthy human microbiome. Nature 486, 207-214. doi: 10.1038/nature11234

Iger, Y., Balm, P. H., Jenner, H. A., and Bonga, S. E. W. (1995). Cortisol induces stress-related changes in the skin of rainbow trout (Oncorhynchus mykiss). Gen. Comp. Endocrinol. 97, 188-198. doi: 10.1006/gcen.1995.1018

Irianto, A., and Austin, B. (2002a). Probiotics in aquaculture. J. Fish Dis. 25, 633-642. doi: 10.1046/j.1365-2761.2002.00422.x

Irianto, A., and Austin, B. (2002b). Use of probiotics to control furunculosis in rainbow trout, Oncorhynchus mykiss (Walbaum). J. Fish Dis. 25, 1-10. doi: 10.1046/j.1365-2761.2002.00375.x

Jensen, S., Ovreas, L., Bergh, O., and Torsvik, V. (2004). Phylogenetic analysis of bacterial communities associated with larvae of the Atlantic halibut propose succession from a uniform normal flora. Syst. Appl. Microbiol. 27, 728-736. doi: $10.1078 / 0723202042369929$

Kanther, M. R. J. (2010). Host-microbe interactions in the developing zebrafish. Curr. Opin. Immunol. 22, 10-19. doi: 10.1016/j.coi.2010.01.006

Kanther, M., Sun, X., Mühlbauer, M., Mackey, L. C., Flynn, E. J. 3rd., Bagnat, M., et al. (2011). Microbial colonization induces dynamic temporal and spatial patterns of NFkappaB activation in the zebrafish digestive tract. Gastroenterology 141, 197-207. doi: 10.1053/j.gastro.2011.03.042

Kanwal, Z., Zakrzewska, A., den Hertog, J., Spaink, H., Schaaf, M., and Meijer, A. (2013). Deficiency in hematopoietic phosphatase ptpn6/Shp1 hyperactivates the innate immune system and impairs control of bacterial infections in zebrafish embryos. J. Immunol. 190, 1631-1645. doi: 10.4049/jimmunol. 1200551

Karlsson, F. H., Tremaroli, V., Nookaew, I., Bergstrom, G., Behre, C. J., Fagerberg, B., et al. (2013). Gut metagenome in European women with normal, impaired and diabetic glucose control. Nature 498, 99-103. doi: 10.1038/nature12198

Kelly, D., Conway, S., and Aminov, R. (2005). Commensal gut bacteria: mechanisms of immune modulation. Trends Immunol. 26, 326-333. doi: 10.1016/j.it.2005.04.008

Kim, D. H., Brunt, J., and Austin, B. (2007). Microbial diversity of intestinal contents and mucus in rainbow trout (Oncorhynchus mykiss). J. Appl. Microbiol. 102, 1654-1664. doi: 10.1111/j.1365-2672.2006.03185.x

Kitano, H., and Oda, K. (2006). Robustness trade-offs and host-microbial symbiosis in the immune system. Mol. Syst. Biol. 2:2006. doi: 10.1038/msb4100039

Korsnes, K., Nicolaisen, O., Skar, C. K., Nerland, A. H., and Bergh, O. (2006). Bacteria in the gut of juvenile cod Gadus morhua fed live feed enriched with four different commercial diets. ICES J. Mar. Sci. 63, 296-301. doi: 10.1016/j.icesjms.2005.10.012

Kühlwein, H., Emery, M. J., Rawling, M. D., Harper, G. M., Merrifield, D. L., and Davies, S. J. (2013). Effects of a dietary $\beta$ - $(1,3)(1,6)$-D-glucan supplementation on intestinal microbial communities and intestinal ultrastructure of mirror carp (Cyprinus carpio L.). J. Appl. Microbiol. 115, 1091-1106. doi: 10.1111/jam.12313

Larsen, A., Tao, Z., Bullard, S. A., and Arias, C. R. (2013). Diversity of the skin microbiota of fishes: evidence for host species specificity. FEMS Microbiol. Ecol. 85, 483-494. doi: 10.1111/1574-6941.12136

Lauzon, H., Gudmundsdottir, S., Petursdottir, S., Reynisson, E., Steinarsson, A., Oddgeirsson, M., et al. (2010). Microbiota of atlantic cod (Gadus morhua L.) rearing systems at pre- and posthatch stages and the effect of different treatments. J. Appl. Microbiol. 109, 1775-1789. doi: 10.1111/j.13652672.2010.04806.x

Le Moullac, G., Soyez, C., Saulnier, D., Ansquer, D., Avarre, J. C., and Levy, P. (1998). Effect of hypoxic stress on the immune response and the resistance to vibriosis of the shrimp Penaeus stylirostris. Fish Shellfish Immunol. 8, 621-629. doi: 10.1006/fsim.1998.0166

Lesley, R., and Ramakrishnan, L. (2008). Insights into early mycobacterial pathogenesis from the zebrafish. Curr. Opin. Microbiol. 11, 277-283. doi: 10.1016/j.mib.2008.05.013

Ley, R. E., Lozupone, C. A., Hamady, M., Knight, R., and Gordon, J. I. (2008). Worlds within worlds: evolution of the vertebrate gut microbiota. Nat. Rev. Microbiol. 6, 776-788. doi: 10.1038/nrmicro1978

Li, X., Yan, Q., Xie, S., Hu, W., Yu, Y., and Hu, Z. (2013). Gut microbiota contributes to the growth of fast-growing transgenic common carp (Cyprinus carpio L.). PLoS ONE 8:e64577. doi: 10.1371/journal.pone.0064577

Li, X., Yu, Y., Feng, W., Yan, Q., and Gong, Y. (2012). Host species as a strong determinant of the intestinal microbiota of fish larvae. J. Microbiol. 50, 29-37. doi: 10.1007/s12275-012-1340-1

Littman, R. A., Bourne, D. G., and Willis, B. L. (2010). Responses of coral-associated bacterial communities to heat stress differ with Symbiodinium type on the same coral host. Mol. Ecol. 19, 1978-1990. doi: 10.1111/j.1365-294X.2010.04620.x

Liu, Y., Zhou, Z., Wu, N., Tao, Y., Xu, L., Cao, Y., et al. (2012). Gibel carp Carassius auratus gut microbiota after oral administration of trimethoprim/ sulfamethoxazole. Dis. Aquat. Org. 99, 207-213. doi: 10.3354/dao02477

Magnadottir, B. (2006). Innate immunity of fish (overview). Fish Shellfish Immunol. 20, 137-151. doi: 10.1016/j.fsi.2004.09.006

Mahious, A. S., and Ollevier, F. (2005). "Probiotics and prebiotics in aquaculture," in 1st Regional Workshop on Techniques for Enrichment for Use in Larviculture2005 (Urmia: AAARC), 67.2545.

Mansfield, G. S., Desai, A. R., Nilson, S. A., Van Kessel, A. G., Drew, M. D., and Hill, J. E. (2010). Characterization of rainbow trout (Oncorhynchus mykiss) intestinal microbiota and inflammatory marker gene expression in a recirculating aquaculture system. Aquaculture 307, 95-104. doi: 10.1016/j.aquaculture.2010.07.014

Marcil, V., Delvin, E., Seidman, E., Poitras, L., Zoltowska, M.,Garofalo, C., et al. (2002). Modulation of lipid synthesis, apolipoprotein biogenesis, and lipoprotein assembly by butyrate. Am. J. Physiol. Gastrointest. Liver Physiol. 283, G340-G346. doi: 10.1152/ajpgi.00440.2001

Mariat, D., Firmesse, O., Levenez, F., Guimarǎes, V., Sokol, H., Doré, J.,et al. (2009.). The Firmicutes/Bacteroidetes ratio of the human microbiota changes with age. BMC Microbiol. 9:123. doi: 10.1186/1471-2180-9-123

Martin-Antonio, B., Manchado, M., Infante, C., Zerolo, R., Labella, A., Alonso, C., et al. (2007). Intestinal microbiota variation in senegalese sole (Solea senegalensis) under different feeding regimes. Aquac. Res. 38, 1213-1222. doi: 10.1111/j.1365-2109.2007.01790.x

Maslowski, K. M., and Mackay, C. R. (2010). Diet, gut microbiota and immune responses. Nat. Immunol. 12, 5-9. doi: 10.1038/ni0111-5

Mazmanian, S. K., and Kasper, D. L. (2006). The love-hate relationship between bacterial polysaccharides and the host immune system. Nat. Rev. Immunol. 6, 849-858. doi: 10.1038/nri1956

Medzhitov, R., and Janeway, C. A. (1999). Innate immune induction of the adaptive immune response. Cold Spring Harb. Symp. Quant. Biol. 64, 429-436. doi: 10.1101/sqb.1999.64.429

Merrifield, D. L., Dimitroglou, A., Foey, A., Davies, S. J., Baker, R. T. M., Bøgwald, J., et al. (2010). The current status and future focus of probiotic and prebiotic applications for salmonids. Aquaculture 302, 1-18. doi: 10.1016/j.aquaculture.2010.02.007

Merrifield, D. L., Shaw, B. J., Harper, G. M., Saoud, I. P., Davies, S. J., Handy, R. D., et al. (2013). Ingestion of metal-nanoparticle contaminated food disrupts endogenous microbiota in zebrafish (Danio rerio). Environ. Pollut. 174, 157-163. doi: 10.1016/j.envpol.2012.11.017 
Moloney, R., Desbonnet, L., Clarke, G., Dinan, T., and Cryan, J. (2013). The microbiome: stress, health and disease. Mamm. Genome 25, 1-26. doi: 10.1007/s00335-013-9488-5

Moran, D., Turner, S. J., and Clements, K. D. (2005). Ontogenetic development of the gastrointestinal microbiota in the marine herbivorous fish Kyphosus sydneyanus. Microb. Ecol. 49, 590-597. doi: 10.1007/s00248-0040097-4

Morgan, X. C., Tickle, T. L., Sokol, H., Gevers, D., Devaney, K. L., Ward, D. V., et al. (2012). Dysfunction of the intestinal microbiome in inflammatory bowel disease and treatment. Genome Biol. 13:R79. doi: 10.1186/gb-2012-13-9-r79

Navarrete, P., Espejo, R. T., and Romero, J. (2009). Molecular analysis of microbiota along the digestive tract of juvenile atlantic salmon (Salmo salar L.). Microb. Ecol. 57, 550-561. doi: 10.1007/s00248-008-9448-x

Navarrete, P., Magne, F., Araneda, C., Fuentes, P., Barros, L., Opazo, R., et al. (2012). PCR-TTGE analysis of $16 \mathrm{~S}$ rRNA from rainbow trout (Oncorhynchus mykiss) gut microbiota reveals host-specific communities of active bacteria. PLOS ONE 7:e31335. doi: 10.1371/journal.pone.0031335

Navarrete, P., Mardones, P., Opazo, R., Espejo, R., and Romero, J. (2010). Oxytetracycline treatment reduces bacterial diversity of intestinal microbiota of atlantic salmon. J. Aquat. Anim. Health 20, 177-183. doi: 10.1577/H07-043.1

Newaj-Fyzul, A., Al-Harbi, A. H., and Austin, B. (2013). Review: developments in the use of probiotics for disease control in aquaculture. Aquaculture. doi: 10.1016/j.aquaculture.2013.08.026. (in press).

Ni, J., Yu, Y., Zhang, T., and Gao, L. (2012). Comparison of intestinal bacterial communities in grass carp, Ctenopharyngodon idellus, from two different habitats. Chin. J. Oceanol. Limnol. 30, 757-765. doi: 10.1007/s00343-012-1287-4

O’Mahony, C., Scully, P., O’Mahony, D., Murphy, S., O’Brien, F., Lyons, A., et al. (2008). Commensal-induced regulatory $\mathrm{T}$ cells mediate protection against pathogen-stimulated NF-кB activation. PLoS Pathog. 4:e1000112. doi: 10.1371/journal.ppat.1000112

O’Mahony, S. M., Marchesi, J. R., Scully, P., Codling, C., Ceolho, A. -M., Quigley, E. M., et al. (2009). Early life stress alters behavior, immunity, and microbiota in rats: implications for irritable bowel syndrome and psychiatric illnesses. Biol. Psychiatry 65, 263-267. doi: 10.1016/j.biopsych.2008.06.026

Palmer, C., Bik, E., DiGiulio, D., Relman, D., and Brown, P. (2007). Development of the human infant intestinal microbiota. PLoS Biol. 5:e177. doi: 10.1371/journal.pbio.0050177

Palti, Y. (2011). Toll-like receptors in bony fish: from genomics to function. Dev. Comp. Immunol. 35, 1263-1272. doi: 10.1016/j.dci.2011.03.006

Pavey, S. A., Sevellec, M., Adam, W., Normandeau, E., Lamaze, F. C., Gagnaire, P. A., et al. (2013). Nonparallelism in MHCIIbeta diversity accompanies nonparallelism in pathogen infection of lake whitefish (Coregonus clupeaformis) species pairs as revealed by next-generation sequencing. Mol. Ecol. 22, 3833-3849. doi: $10.1111 / \mathrm{mec} .12358$

Perez-Cobas, A. E., Gosalbes, M. J., Friedrichs, A., Knecht, H., Artacho, A., Eismann, K., et al. (2013). Gut microbiota disturbance during antibiotic therapy: a multi-omic approach. Gut 62, 1591-1601. doi: 10.1136/gutjnl-2012303184

Pulkkinen, K., Suomalainen, L. -R., Read, A. F., Ebert, D., Rintamäki, P., and Valtonen, E. T. (2010). Intensive fish farming and the evolution of pathogen virulence: the case of columnaris disease in Finland. Proc. R. Soc. B Biol. Sci. 277, 593-600. doi: 10.1098/rspb.2009.1659

Qin, J., Li, R., Raes, J., Arumugam, M., Burgdorf, K. S., Manichanh, C., et al. (2010). A human gut microbial gene catalogue established by metagenomic sequencing. Nature 464, 59-65. doi: 10.1038/nature08821

Rakers, S., Gebert, M., Uppalapati, S., Meyer, W., Maderson, P., Sell, A. F., et al. (2010). "Fish matters": the relevance of fish skin biology to investigative dermatology. Exp. Dermatol. 19, 313-324. doi: 10.1111/j.1600-0625.2009.01059.x

Rakoff-Nahoum, S., Paglino, J., Eslami-Varzaneh, F., Edberg, S., and Medzhitov, R. (2004). Recognition of commensal microflora by Toll-Like receptors is required for intestinal homeostasis. Cell 118, 229-241. doi: 10.1016/j.cell.2004.07.002

Rawls, J. F., Mahowald, M. A., Ley, R. E., and Gordon, J. I. (2006). Reciprocal gut microbiota transplants from zebrafish and mice to germ-free recipients reveal host habitat selection. Cell 127, 423-433. doi: 10.1016/j.cell.2006.08.043

Rawls, J., Samuel, B., and Gordon, J. (2004). Gnotobiotic zebrafish reveal evolutionarily conserved responses to the gut microbiota. Proc. Natl. Acad. Sci. U.S.A. 101, 4596-4601. doi: 10.1073/pnas.0400706101

Reid, H. I., Treasurer, J. W., Adam, B., and Birkbeck, T. H. (2009). Analysis of bacterial populations in the gut of developing cod larvae and identification of
Vibrio logei, Vibrio anguillarum and Vibrio splendidus as pathogens of cod larvae. Aquaculture 288, 36-43. doi: 10.1016/j.aquaculture.2008.11.022

Rekecki, A., Ringø, E., Olsen, R., Myklebust, R., Dierckens, K., Bergh, O. S., et al. (2013). Luminal uptake of Vibrio (Listonella) anguillarum by shed enterocytesa novel early defence strategy in larval fish. J. Fish Dis. 36, 419-426. doi: 10.1111/jfd.12009

Rendueles, O., Ferrières, L., Frétaud, M., Bégaud, E., Herbomel, P., Levraud, J., et al. (2013). A new zebrafish model of oro-intestinal pathogen colonization reveals a key role for adhesion in protection by probiotic bacteria. PLoS Pathog. 8:e1002815. doi: 10.1371/journal.ppat.1002815

Ridaura, V. K., Faith, J. J., Rey, F. E., Cheng, J., Duncan, A. E., Kau, A. L., et al. (2013). Gut microbiota from twins discordant for obesity modulate metabolism in mice. Science 341:1241214. doi: 10.1126/science.1241214

Ringø, E., Dimitroglou, A., Hoseinifar, S. H., and Davies, S. J. (2014). "Prebiotics in finfish: an update," in Aquaculture Nutrition: Gut Health, Probiotics and Prebiotics, Edn 1, eds D. L. Merrifield and E. Ringø (Hoboken, NJ: WileyBlackwell Scientific Publication).

Ringø, E., Olsen, R. E., Gifstad, T. Ø., Dalmo, R. A., Amlund, H., Hemre, G. I., et al., (2010). Prebiotics in aquaculture: a review. Aquacult. Nutr. 169, 117-136. doi: 10.1111/j.1365-2095.2009.00731.x

Ringø, E., Sperstad, S., Myklebust, R., Refstie, S., and Krogdahl, A. (2006). Characterisation of the microbiota associated with intestine of Atlantic cod (Gadus morhua L.): The effect of fish meal, standard soybean meal and a bioprocessed soybean meal. Aquaculture 261, 829-841.

Roberfroid, M. (2007). Prebiotics: the concept revisited. J. Nutr. 137, 830S-837S.

Roeselers, G., Mittge, E. K., Stephens, W. Z., Parichy, D. M., Cavanaugh, C. M., Guillemin, K., et al. (2011). Evidence for a core gut microbiota in the zebrafish. ISME J. 5, 1595-1608. doi: 10.1038/ismej.2011.38

Romero, J., and Navarrete, P. (2006). 16S rDNA-based analysis of dominant bacterial populations associated with early life stages of coho salmon (Oncorhynchus kisutch). Microb. Ecol. 38, 1-26. doi: 10.1007/s00248-006-9037-9

Rurangwa, E., Laranja, J. L., Van Houdt, R., Delaedt, Y., Geraylou, Z., Van de Wiele, T., et al. (2009). Selected nondigestible carbohydrates and prebiotics support the growth of probiotic fish bacteria mono cultures in vitro. J. Appl. Microbiol. 106, 932-940. doi: 10.1111/j.1365-2672.2008.04034.x

Sanchez-Paz, A. (2010). White spot syndrome virus: an overview on an emergent concern. Vet. Res. 41:43. doi: 10.1051/vetres/2010015

Schimel, J., Balser, T. C., and Wallenstein, M. (2007). Microbial stress-response physiology and its implications for ecosystem function. Ecology 88, 1386-1394. doi: 10.1890/06-0219

Semova, I., Carten, J. D., Stombaugh, J., Mackey, L. C., Knight, R., Farber, S. A., et al. (2012). Microbiota regulate intestinal absorption and metabolism of fatty acids in the zebrafish. Cell Host Microbe 12, 277-288. doi: 10.1016/j.chom.2012. 08.003

Shiina, A., Itoi, S., Washio, S., and Sugita, H. (2006). Molecular identification of intestinal microflora in Takifugu niphobles. Comp. Biochem. and Physiol. Part D Genomics Proteomics 1, 128-132. doi: 10.1016/j.cbd.2005.10.001

Silva, F. C., Nicoli, J. R., Zambonino-Infante, J. L., Kaushik, S., and Gatesoupe, J. F. (2011). Influence of the diet on the microbial diversity of faecal and gastrointestinal contents in gilthead sea bream (Sparus aurata) and intestinal contents in goldfish (Carassius auratus). FEMS Microbiol. Ecol. 78, 285-296. doi: 10.1111/j.1574-6941.2011.01155.x

Skrodenyte-Arbaciauskiene, V., Sruoga, A., and Butkauskas, D. (2006). Assessment of microbial diversity in the river trout Salmo trutta fario L. intestinal tract identified by partial 16S rRNA gene sequence analysis. Fish. Sci. 72, 597-602. doi: 10.1111/j.1444-2906.2006.01189.x

Skrodenyte-Arbaciauskiene, V., Sruoga, A., Butkauskas, D., and Skrupskelis, K. (2008). Phylogenetic analysis of intestinal bacteria of freshwater salmon Salmo salar and sea trout Salmo trutta trutta and diet. Fish. Sci. 74, 1307-1314. doi: 10.1111/j.1444-2906.2008.01656.x

Smriga, S., Sandin, S. A., and Azam, F. (2010). Abundance, diversity, and activity of microbial assemblages associated with coral reef fish guts and feces. FEMS Microbiol. Ecol. 73, 31-42. doi: 10.1111/j.1574-6941.2010.00879.x

Snieszko, S. F. (1974). The effects of environmental stress on outbreaks of infectious diseases of fishes. J. Fish Biol. 6, 197-208. doi: 10.1111/j.1095-8649.1974. tb04537.x

Spor, A., Koren, O., and Ley, R. (2011). Unravelling the effects of the environment and host genotype on the gut microbiome. Nat. Rev. Microbiol. 9, 279-290. doi: $10.1038 /$ nrmicro 2540 
Star, B., Haverkamp, T. H., Jentoft, S., and Jakobsen, K. S. (2013). Next generation sequencing shows high variation of the intestinal microbial species composition in Atlantic cod caught at a single location. BMC Microbiol. 13:248. doi: 10.1186/1471-2180-13-248

Stecher, B., and Hardt, W. D., (2008). The role of microbiota in infectious disease. Trends Microbiol. 16, 107-114. doi: 10.1016/j.tim.2007.12.008

Sudo, N., Chida, Y., Aiba, Y., Sonoda, J., Oyama, N., Yu, X. N., et al. (2004). Postnatal microbial colonization programs the hypothalamic-pituitary-adrenal system for stress response in mice. J. Physiol. (Lond). 558, 263-275. doi: 10.1113/jphysiol.2004.063388

Sun, Y., Yang, H., Ling, Z., Chang, J., and Ye, J. (2009). Gut microbiota of fast and slow growing grouper Epinephelus coioides. Afr. J. Microbiol. Res. 3, 637-640.

Svanevik, C. S., and Lunestad, B. T. (2011). Characterisation of the microbiota of Atlantic mackerel (Scomber scombrus). Int. J. Food Microbiol. 151, 164-170. doi: 10.1016/j.ijfoodmicro.2011.08.016

Tapia-Paniagua, S., Chabrillón, M., Díaz-Rosales, P., Banda, I., Lobo, C., Balebona, M. C.,et al. (2010). Intestinal microbiota diversity of the flat fish Solea senegalensis (Kaup, 1858) following probiotic administration. Microb. Ecol. 60, 310-319. doi: 10.1007/s00248-010-9680-z

Tellez, G., Higgins, S., Donoghue, A., and Hargis, B. (2006). Digestive physiology and the role of microorganisms. J. Appl. Poult. Res. 15, 136-144. doi: 10.1093/japr/15.1.136

Tetlock, A., Yost, C. K., Stavrinides, J., and Manzon, R. G. (2012). Changes in the gut microbiome of the sea lamprey during metamorphosis. Appl. Environ. Microbiol. 78, 7638-7644. doi: 10.1128/AEM.01640-12

Thurber, R. V., Willner-Hall, D., Rodriguez-Mueller, B., Desnues, C., Edwards, R. A., Angly, F., et al. (2009). Metagenomic analysis of stressed coral holobionts. Environ. Microbiol. 11, 2148-2163. doi: 10.1111/j.1462-2920.2009.01935.x

Turnbaugh, P. J., Hamady, M., Yatsunenko, T., Cantarel, B. L., Duncan, A., Ley, R. E., et al. (2009a). A core gut microbiome in obese and lean twins. Nature 457, 480-484. doi: 10.1038/nature07540

Turnbaugh, P. J., Ley, R. E., Mahowald, M. A., Magrini, V., Mardis, E. R., and Gordon, J. I. (2006). An obesity-associated gut microbiome with increased capacity for energy harvest. Nature 444, 1027-1031. doi: 10.1038/nature05414

Turnbaugh, P. J., Ridaura, V. K., Faith, J. J., Rey, F. E., Knight, R., and Gordon, J. I. (2009b). The effect of diet on the human gut microbiome: a metagenomic analysis in humanized gnotobiotic mice. Sci. Transl. Med. 1:6ra14. doi: 10.1126/scitranslmed.3000322

Valdenegro-Vega, V., Naeem, S., Carson, J., Bowman, J. P., Tejedor del Real, J. L., and Nowak, B. (2013). Culturable microbiota of ranched southern bluefin tuna (Thunnus maccoyii Castelnau). J. Appl. Microbiol. 115, 923-932. doi: 10.1111/jam.12286

van der Sar, A., Appelmelk, B., Vandenbroucke-Grauls, C., and Bitter, W. (2004). A star with stripes: zebrafish as an infection model. Trends Microbiol. 12, 451-457. doi: 10.1016/j.tim.2004.08.001

Verbrugghe, E., Boyen, F., Gaastra, W., Bekhuis, L., Leyman, B., Van Parys, A., et al. (2012). The complex interplay between stress and bacterial infections in animals. Vet. Microbiol. 155, 115-127. doi: 10.1016/j.vetmic.2011.09.012
Verner-Jeffreys, D., Shields, R., and Birkbeck, T. (2003). Bacterial influences on Atlantic halibut Hippoglossus hippoglossus yolk-sac larval survival and start-feed response. Dis. Aquat. Org. 56, 105-113. doi: 10.3354/ dao056105

Wakabayashi, H. (1991). Effect of environmental conditions on the infectivity of Flexibacter columnaris to fish. J. Fish Dis. 14, 279-290. doi: 10.1111/j.13652761.1991.tb00825.x

Ward, N., Steven, B., Penn, K., Methé, B., and Detrich, W. III. (2009). Characterization of the intestinal microbiota of two Antarctic notothenioid fish species. Extremophiles 13, 679-685. doi: 10.1007/s00792-0090252-4

Wells, C. L., Maddaus, M. A., Jechorek, R. P., and Simmons, R. L. (1988). Role of intestinal anaerobic bacteria in colonization resistance. Eur. J. Clin. Microbiol. Infect. Dis. 7, 107-113. doi: 10.1007/BF01962194

Wendelaar Bonga, S. E. (1997). The stress response in fish. Physiol. Rev. 77, 591-625.

Wu, S., Tian, J., Wang, G., Li, W., and Zou, H. (2012a). Characterization of bacterial community in the stomach of yellow catfish (Pelteobagrus fulvidraco). World J. Microbiol. Biotechnol. 28, 2165-2174. doi: 10.1007/s11274-0121022-5

Wu, S., Wang, G., Angert, E. R., Wang, W., Li, W., and Zou, H. (2012b). Composition, diversity, and origin of the bacterial community in grass carp intestine. PLoS ONE 7:e30440. doi: 10.1371/journal.pone.0030440

Ye, L., Amberg, J., Chapman, D., Gaikowski, M., and Liu, W. T. (2014). Fish gut microbiota analysis differentiates physiology and behavior of invasive Asian carp and indigenous American fish. ISME J. 8, 541-551. doi: 10.1038/ismej.2013.181

Yoshimizu, M., Kimura, T., and Sakai, M. (1980). Microflora of the embryo and the fry of salmonids. Bull. Jpn. Soc. Sci. Fish 46, 967-975. doi: 10.2331/suisan.46.967

Zhou, Z., Karlsen, Ø., He, S., Olsen, R. E., Yao, B., and Ringø, E. (2012). The effect of dietary chitin on the autochthonous gut bacteria of Atlantic cod (Gadus morhua L.). Aquac. Res. 44, 1889-1900.

Conflict of Interest Statement: The authors declare that the research was conducted in the absence of any commercial or financial relationships that could be construed as a potential conflict of interest.

Received: 14 January 2014; accepted: 18 April 2014; published online: 02 June 2014. Citation: Llewellyn MS, Boutin S, Hoseinifar SH and Derome N (2014) Teleost microbiomes: the state of the art in their characterization, manipulation and importance in aquaculture and fisheries. Front. Microbiol. 5:207. doi: 10.3389/fmicb.2014.00207 This article was submitted to Aquatic Microbiology, a section of the journal Frontiers in Microbiology.

Copyright (c) 2014 Llewellyn, Boutin, Hoseinifar and Derome. This is an openaccess article distributed under the terms of the Creative Commons Attribution License (CC BY). The use, distribution or reproduction in other forums is permitted, provided the original author(s) or licensor are credited and that the original publication in this journal is cited, in accordance with accepted academic practice. No use, distribution or reproduction is permitted which does not comply with these terms. 